\title{
War, Tropical Disease, and the Emergence of National Public Health Capacity in the United States
}

\section{Daniel Sledge, The University of Texas at Arlington}

\begin{abstract}
This article analyzes the emergence of national public health capacity in the United States. Tracing the transformation of the federal government's role in public health from the 1910s through the emergence of the CDC during World War II, I argue that national public health capacity emerged, to a great extent, out of the attempts of government officials to deal with the problem of tropical disease within the southern United States during periods of mobilization for war.
\end{abstract}

On December 10, 1898, the United States and Spain signed the Treaty of Paris, bringing a formal end to the Spanish-American War and granting the United States possession of the Philippines, Puerto Rico, and Guam. ${ }^{1}$ Along with these territories, the United States began an occupation of Cuba, home to the insurgency against Spanish rule whose brutal suppression had played a prominent role in the American decision to go to war.

American authorities in Cuba were particularly concerned with the problem of yellow fever on the island. In the fall of 1897 , as tension between the United States and Spain rose, an epidemic of yellow fever had spread through the American South. The outbreak was widely-and correctly-believed to have been sparked by Cuban refugees in coastal Mississippi, fueling calls to bring an end to the threat to American health emanating from the island. ${ }^{2}$

Once in control of Havana, U.S. authorities quickly moved to "clean up" the city, operating under the mistaken understanding that yellow fever was a disease of filth, reaching its victims largely through unsanitary

I thank Richard Bensel, Theodore Lowi, Elizabeth Sanders, two anonymous reviewers, and the editors of Studies in American Political Development for their input and feedback. Thanks to Jenna Green for her ongoing help and also to George, David, and Carolyn Sledge for reading various drafts.

1. See Michael H. Hunt, The American Ascendancy: How the United States Gained and Wielded Global Dominance (Chapel Hill: University of North Carolina Press, 2007), 47.

2. This account follows Mariola Espinosa, Epidemic Invasions: Yellow Fever and the Limits of Cuban Independence, 1878-1930 (Chicago: University of Chicago Press, 2009). Espinosa argues persuasively that the ongoing threat of yellow fever in Havana to health in the United States was an important source of tension between the United States and Spain. urban conditions. ${ }^{3}$ The American occupation's efforts, however, proved a disappointing failure: despite the implementation of stringent sanitary measures, yellow fever continued to thrive.

In response, the Americans created a Yellow Fever Commission, headed by U.S. Army medical officer Walter Reed and charged with rethinking the causes of the disease. ${ }^{4}$ Inspired in part by the Cuban physician Carlos Finlay (who had argued since the 1880s that yellow fever was spread by mosquitoes) and in part by the work of American Henry Rose Carter (whose research suggested that the disease required a period of incubation in an intermediary host such as the mosquito) the Yellow Fever Commission soon determined that the disease was being spread not by filth but by Havana's large mosquito population. ${ }^{5}$

The consequences of this finding were significant. U.S. authorities under the command of the U.S. Army's William Gorgas quickly began work on the development of techniques for destroying the breeding sites of Havana's mosquitoes and limiting the transmission of yellow fever. Successful and increasingly confident, they broadened their efforts, developing techniques to control the breeding of the Anopheles mosquitoes that spread malaria in Cuba. ${ }^{6}$ Though not fully eliminated, both diseases soon

3. Ibid., 15, 34.

4. See Ibid., 57-63.

5. Ibid., 57, 59 .

6. On the development of mosquito control techniques in Cuba, see particularly Joseph A. LePrince and A.J. Orenstein, Mosquito Control in Panama: The Eradication of Malaria and Yellow Fever in Cuba and Panama (New York: G.P. Putnam's Sons, 1916). 
came to represent far less significant health threats than they had before.

In 1904, the United States began construction of the Panama Canal, an enterprise that (as the failed earlier French attempt to build a canal across the Panamanian isthmus made clear) would have been impossible without the knowledge of how to control mosquito-borne illnesses that had been developed in Cuba. William Gorgas again supervised the work.

A source of pride for many Americans, Gorgas's successes abroad had the effect in part of highlighting limitations on the authority of the federal government at home. ${ }^{7}$ Yellow fever was a serious but essentially episodic threat: on occasion introduced from abroad (often from Cuba), it then pulsed through the cities and towns of the South. Malaria, however, was a constant and well-entrenched presence, an inescapable aspect of daily life throughout large swaths of the southern United States.

Why did the United States work to control the spread of malaria in its new overseas territories but make no effort to do so at home? The answer is fairly straightforward. Public health was understood, above all else, as a police power, left to the states under the 10th Amendment to the Constitution. In a landmark 1905 decision affirming the power of states to compel compliance with public health efforts such as mandatory vaccination for smallpox, Supreme Court Justice John Marshall Harlan articulated the prevailing understanding of the appropriate role of the federal government, asserting "the primacy of state over federal authority in the realm of public health." 8 Safety and health, Justice Harlan wrote, were "in the first instance" matters of concern for the states: "They are matters that do not ordinarily concern the National Government."

Speaking in 1909, progressive Congressman Frederick Stevens (R-MN) explained that " $[\mathrm{t}]$ he only jurisdiction Congress has is under the commerce clause of the Constitution. We have no jurisdiction at all over health as a separate and independent subject. The

7. President William Howard Taft speaking in Augusta, Georgia, in 1909, noted that "We pride ourselves on having done something that France was not able to do ... but we must remember that she did not then have at her command the knowledge which we have had in the suppression of the disease that made life on that Isthmus so dangerous to every one who attempted to live there. The consequence is that to-day we have less malaria, or certainly not more on the Isthmus of Panama than you have in your Southern States." See William Howard Taft, "Sanitation and Health of the South, Remarks at the Georgia-Carolina Fair, Augusta, Ga., November 8, 1909," in Presidential Addresses and State Papers of William Howard Taft, from March 4, 1909, to March 4, 1910 (New York: Doubleday, Page \& Company, 1910), 421.

8. Lawrence O. Gostin, Public Health Law: Power, Duty, Restraint, Second ed. (Berkeley: University of California Press, 2008), 121.

9. Quoted in Gostin, Public Health Law, 121. Harlan wrote specifically about the power of the Commonwealth of Massachusetts to pass legislation enabling local boards of health to compel vaccination for diseases such as smallpox.
Constitution left that entirely within the control of the States. We can not, if we would, deprive the States of those police powers to control the health and welfare of their people."10

As the United States worked to control tropical diseases in its new overseas dependencies, federal public health efforts within the United States were limited almost entirely to the operation of hospitals for sailors and quarantine efforts in some coastal cities. Understandings of the appropriate role of the federal government in public health that stressed the reserved powers of the states were well entrenched. Beginning with American entry into World War I, however, the federal government's role in public health would gradually be transformed. By the end of World War II, the federal government would possess a broad capacity to coordinate public health interventions across political jurisdictions and to influence local-level public health policy and activities.

Centered in the U.S. Public Health Service's (PHS) States Relations Division, these capacities soon flowed almost entirely to the division's Atlanta-based Communicable Disease Center. An outgrowth of the PHS's World War II Malaria Control in War Areas Program, the agency was later renamed the Centers for Disease Control (CDC).

\section{WAR, TROPICAL DISEASE, AND NATIONAL PUBLIC HEALTH CAPACITY IN THE UNITED STATES}

This article analyzes the emergence of national public health capacity in the United States. Tracing the transformation of the federal government's role in public health from the 1910s through the emergence of the CDC during World War II, I argue that national public health capacity emerged, to a great extent, out of the attempts of government officials to deal with the problem of tropical disease within the southern United States during periods of mobilization for war.

Successful mobilization for war requires that governments develop strategies and procedures aimed at marshalling available resources and manpower. As a result, wars often lead to government attempts to centralize authority and develop greater capacities to project authority domestically. ${ }^{11}$ The potential consequences

10. Proposed Department of Public Health: Hearings before the Committee on Public Health and National Quarantine, United States Senate, on the Bill, S. 6049, to Establish a Department of Health and for Other Purposes (Washington, DC: GPO, 1910), 48, quoted in Manfred Waserman, "The Quest for a National Health Department in the Progressive Era," Bulletin of the History of Medicine 49, no. 3 (1975):364.

11. Political scientists have long recognized the role of war in political and institutional development. See particularly Charles Tilly, Coercion, Capital, and European States, AD 990-1992 (Cambridge, MA: B. Blackwell, 1992); Charles Tilly, ed., The Formation of National States in Western Europe (Princeton: Princeton University Press, 1975); Bruce D. Porter, War and the Rise of the State 
of war, of course, are manifold. ${ }^{12}$ In the United States, wars have variously fueled the growth of executive power relative to Congress, resulted in expansions of the right to vote, led to the enactment of laws aimed at restricting free speech and to attempts to suppress dissident voices, and brought an end to the practice of slavery.

As I hope to show, World War I was a pivotal turning point in the development of American public health policy. By 1917, it was increasingly evident that the American South was, within the nation, uniquely subject to debilitating diseases such as malaria, hookworm (an intestinal parasite that causes irondeficiency anemia), and pellagra (a dietary deficiency disease that plagued areas where the economy was dominated by cotton monoculture).

A growing awareness of the threat posed by malaria to troops stationed in the southern United States convinced national officials that federal action at the local level was a necessary component of a successful mobilization. As a result, long-standing reservations about the national government's exercise of public health authority were set aside or negotiated through arrangements such as the appointment of federal officials as agents of state departments of health. Approaches to controlling disease developed by Americans abroad were, in effect, imported back into the United States.

For the Public Health Service, successful participation in war mobilization appeared to represent an opening for expanded active public health work in the postwar period. Congress, however, would prove largely uninterested in the efforts of PHS officers and their supporters to expand the federal presence in local-level public health efforts into the postwar era.

Denied the full-scale grant-in-aid program that they had hoped to secure following the war, PHS officers nonetheless attempted to extend their cooperation with local officials beyond the wartime emergency. Operating with a limited budget and little meaningful oversight from Congress, PHS officers continued to offer expertise, personnel, and funding for local public health efforts in the years following World War I, building a base of knowledge and relationships that would ultimately lead to a transformation of the national government's role in public health.

The relationships of PHS officials with state and local governments as well as with southern representatives in Congress were further strengthened in the

(New York: The Free Press, 1994); Robert P. Saldin, War, the American State, and Politics since 1898 (New York: Cambridge University Press, 2011); Richard Bensel, Yankee Leviathan: The Origins of Central State Authority in America, 1859-1877 (New York: Cambridge University Press, 1990).

12. For a particularly thoughtful and broad analysis of the potential impacts of war on governing structures (which include wholesale destruction), see Porter, War and the Rise of the State. aftermath of two successive natural disasters: the 1927 flood of the Mississippi River and the massive drought of 1930-1931. ${ }^{13}$

On the basis of the political support for its efforts that PHS officers had begun cultivating during World War I, the PHS's small-scale program for the development of local public health infrastructure was included in the 1935 Social Security Act, gaining a greatly expanded mandate and budget. When the nation become involved in World War II, the federal role in attempting to coordinate state and local public health efforts was further centralized in the form of the Atlanta-based Malaria Control in War Areas Program, renamed the Communicable Disease Center in 1946.

Although national public health capacity is a critical component of government in the contemporary United States, political scientists have largely ignored its emergence. For the most part, political scientists concerned with health politics and policy in the United States have focused on other issues, producing excellent studies of the role of the federal tax code in incentivizing employers to offer health insurance, the failure of different plans for providing national health insurance, the passage of the 2010 Patient Protection and Affordable Care Act, and the development and political contours of Medicare and, to a lesser extent, Medicaid. ${ }^{14}$

13. Focusing events (crises or disasters that draw the attention or can be used to draw the attention of political actors capable of enacting, altering, or expanding policies) have long played a role in analyses of public policy. See particularly John Kingdon, Agendas, Alternatives, and Public Policies, 2nd ed. (New York: Longman Classics in Political Science, 2003); Frank R. Baumgartner and Bryan D. Jones, Agendas and Instability in American Politics, 2nd ed. (Chicago: University of Chicago Press, 2009); Daniel Carpenter and Gisela Sin, "Policy Tragedy and the Emergence of Regulation: The Food, Drug, and Cosmetic Act of 1938," Studies in American Political Development 21(2007).

14. On health insurance and the federal government, see particularly Jacob S. Hacker, The Divided Welfare State: The Battle over Public and Private Social Benefits in the United States (New York: Cambridge University Press, 2002); Jacob S. Hacker, "The Historical Logic of National Health Insurance: Structure and Sequence in the Development and British, Canadian, and U.S. Medical Policy," Studies in American Political Development 12(1998); Suzanne Mettler, The Submerged State: How Invisible Government Policies Undermine American Democracy (Chicago: University of Chicago Press, 2011); David Blumenthal and James A. Morone, The Heart of Power: Health and Politics in the Oval Office (Berkeley: University of California Press, 2009); Theda Skocpol, Boomerang: Health Care Reform and the Turn against Government (New York: W.W. Norton and Company, 1997); Paul Starr, Remedy and Reaction: The Peculiar American Struggle over Health Care Reform (New Haven, CT: Yale University Press, 2011). On Medicare, see Jonathan Oberlander, The Political Life of Medicare (Chicago: University of Chicago Press, 2003); Theodore R. Marmor, The Politics of Medicare, 2nd ed. (Hawthorne, NY: Aldine De Gruyter, 2000); JonathanOberlander, "Through the Looking Glass: The Politics of the Medicare Prescription Drug, Improvement, and Modernization Act," Journal of Health Politics, Policy, and Law 32, no. 2 (2007). On Medicaid, see Laura Katz Olson, The Politics of Medicaid (New York: Columbia Univeristy Press, 2010). 
In part because of disciplinary boundaries (between political science, public health, and the history of medicine), and in part because of the sharp distinctions that scholars often draw between the Progressive Era, the 1920s, the New Deal, and World War II, the transformation of the role of the federal government in public health that I discuss in this article has not yet been examined. ${ }^{15}$

This lack of attention is unfortunate. To begin with, public health efforts and infrastructure play a central role in daily life and in community and national well-being. If successful, of course, they may swiftly become invisible or overlooked. Along with their potential impact on the health of populations, public health interventions are often associated with distinct and potentially interesting political dynamics. As Daniel Carpenter has suggested, health politics often involves issuesincluding claims to access to services grounded in equity and social justice, questions of individual and community identity, and the role of technology and professional expertise-that often render it different from other fields of inquiry for political scientists. Existing theories and models are often poorly suited for understanding the politics that emerge around issues such as health insurance and the delivery of health services. ${ }^{16}$

Within the realm of health politics and policy, public health is further distinguished in at least two aspects: the unclear and contested nature of its boundaries and the novel ways in which public health

15. John Ettling, for instance, has written an authoritative account of the Rockefeller Sanitary Commission's 1910-1915 campaign against hookworm disease. In addition to detailing the work of the Sanitary Commission in the United States, Ettling's Germ of Laziness is impressively attentive to the impact of international factors (particularly the campaign against hookworm in Puerto Rico) on domestic developments. Because of its focus on the period ending in 1915, however, Ettling's work does not address the work of the Rockefeller International Health Board in the United States or the later institutionalization of public health work in the South. See John Ettling, The Germ of Laziness (Cambridge, MA: Harvard University Press, 1981). William Link's Paradox of Southern Progressivism offers a thorough discussion of the Sanitary Commission and also contains an excellent account of the early role of the International Health Board in stimulating the development of systematic public health work in the South. In focusing on the Progressive Era, however, Link cuts his narrative short before the crucial 1930s. In addition, Link largely ignores international influences on domestic public health policy. He does not deal with the impact of World War I and is for the most part unconcerned with the role of the Public Health Service. See William A. Link, The Paradox of Southern Progressivism, 1880-1930, The Fred W. Morrison Series in Southern Studies (Chapel Hill: University of North Carolina Press, 1992). This article is greatly influenced by Link's work, which, particularly in its consideration of the relationship between public health workers and the communities in which they attempted to operate, has had a significant impact on my approach to understanding public health interventions.

16. Daniel Carpenter, "Is Health Politics Different?" The Annual Review of Political Science 15 (2012). interventions engage, regulate, and impose upon individuals and communities. Almost by definition, public health is a potentially expansive and even invasive endeavor. Accepting a legitimate role for government in attempting to regulate and ensure "public" health raises difficult questions about where to draw the lines between individual liberty, privacy, and community well-being. As Paul Starr writes, "The maintenance of the public's health allows-some would say demands-concern with almost every aspect of life." 17 Measures as diverse as the lowering of speed limits, mandatory vaccination, construction of sewers, tracking of sexually transmitted disease, and gun control might plausibly be framed as necessary for the preservation of the health of the public. ${ }^{18}$

Two well-known definitions of public health suggest the protean nature of the concept. For the influential American theorist and practitioner C.E.A. Winslow, public health meant

the science and the art of preventing disease, prolonging life, and promoting physical health and efficiency through organized community efforts for the sanitation of the environment, the control of community infections, the education of the individual in principles of personal hygiene, the organization of medical and nursing service for the early diagnosis and preventive treatment of disease, and the development of the social machinery which will ensure to every individual in the community a standard of living adequate for the maintenance of health. ${ }^{19}$

In its 1988 report on The Future of Public Health, meanwhile, The Institute of Medicine offered a more succinct if comparably broad definition, defining "the mission of public health as fulfilling society's interest in assuring conditions in which people can be healthy." 20

National public health capacity refers to the ability of the federal government to assess threats to public health, develop responses, and implement them, whether through the encouragement of state and local action, encouragement of private action, regulation, or direct delivery of services. ${ }^{21}$ In using this

17. Paul Starr, The Social Transformation of American Medicine (New York: Basic Books, 1982), 180.

18. On the potential expansiveness of health interventions, see also Rogan Kersh and James Morone, "How the Personal Becomes Political: Prohibitions, Public Health, and Obesity," Studies in American Political Development 16 (2002).

19. Quoted in Starr, Social Transformation of American Medicine, 180.

20. Institute of Medicine Committee for the Study of the Future of Public Health, The Future of Public Health (Washington, DC: National Academy Press, 1988), 7.

21. This definition of health capacity is based on the Institute of Medicine's enumeration of core public health functions. See The Future of Public Health. The IOM's core functions are: 1) assessment (the ability to assess the nature and extent of health problems); 2) policy development; and 3) assurance (the ability to implement public health interventions). 
term, I hope to evoke both the direct power and authority of the federal government as well as the manifestation of federal power in the form of grants-in-aid, training programs, and the provision of expert advice.

To a substantial degree, national public health capacity in the United States means the contested and far less than complete ability of the federal government to coordinate responses across political jurisdictions and to affect the policy decisions and actions of state and local governments. This capacity grew initially out of federal attempts-underpinned by relationships with local elites-aimed largely at improving the health status of some of the nation's most marginalized populations: low-income southern whites and blacks. As one might expect, discussions about disease in the segregated South were often infused with the language of race. Importantly, however, public health workers developed arguments about the relationship between debilitating diseases and the economic prosperity of individual landowners and employers, communities, and the southern United States as a region. Public health efforts and infrastructure, federal public health officials maintained, would result in less time lost to sickness, higher worker productivity, and the increased attractiveness of the South for potential migrants and outside investors.

The implications of federal intervention in southern public health were massive. Ultimately, the development of local public health infrastructure played a crucial role in eliminating the burden of tropical disease in the South, ridding the region of debilitating diseases-particularly malaria-that represented a significant obstacle to economic development. In attempting to confront the problem of tropical disease in the southern United States, meanwhile, officials from the U.S. Public Health Service developed policies and interpretations of federal public health authority that resulted in a transformation of the role of the federal government in public health throughout the nation. The location of the Centers for Disease Control, near the heart of the nation's former malaria belt, serves as a physical testament to the long-term institutional impact of these efforts.

\section{FEDERAL PUBLIC HEALTH EFFORTS IN THE YEARS BEFORE WORLD WAR I}

In 1909, John D. Rockefeller announced that he would donate $\$ 1$ million to fight hookworm in the American South. The presence of the parasite in the New World had first been recognized in the aftermath of the Spanish-American War, when U.S. Army medical officer Bailey K. Ashford found that it was widespread among the rural inhabitants of Puerto Rico. Between 1904 and 1910, American officials in Puerto Rico treated approximately 287,568 hookworm cases. Including cases that American authorities believed to have been dealt with by private physicians, officials reported that they felt "entirely safe in saying that over 300,000, or nearly one-third of the population of Porto Rico, have received specific treatment for uncinariasis [hookworm]." ${ }^{22}$

In the United States, Charles Wardell Stiles of the United States Public Health and Marine Hospital Service was informed by Ashford (who was a former student of Stiles) of the extent of hookworm infection in Puerto Rico. ${ }^{23}$ After embarking on a preliminary survey of the southern Atlantic coast in 1902, Stiles reported that hookworm was "one of the most important factors in the inferior mental, physical, and financial condition of the poorer classes of the white population of the rural sand and piney woods districts which I visited." 24

The disease, Stiles believed, represented an important threat to the region's economic livelihood, "resulting in loss in wages, loss in productive-ness of the farms, loss in the school attendance of the children, extra expenses for drugs and for physicians' services, etc." 25 Stiles spent the next seven years as something of a lone voice, attempting to spread knowledge of the disease but limited by both resources and a lack of authority. Eventually, he persuaded the John D. Rockefeller philanthropy to become involved, drawing attention to a domestic void in government action that stood in stark contrast to the efforts of American officials in the nation's overseas possessions.

The 1909 creation of the Rockefeller Sanitary Commission for the Eradication of Hookworm, near the height of the Progressive Era push for a national department of health and six and a half years before the United States entered World War I, can serve as a useful starting point for an understanding of the extent of the change involved in the federal role in public health between the 1910s and the end of World War II. As of 1909, the Public Health and Marine Hospital Service was the federal government's principle health-related agency. Importantly, many of the service's functions were relatively new. Since its founding in 1798, the central job of the agency-known as the Marine Hospital Service until

22. Bailey K. Ashford and Pedro Gutierrez Igaravidez, Uncinariasis (Hookworm Disease) in Porto Rico, Senate Document No. 808 (Washington, DC: GPO, 1911), 35.

23. Stiles worked for the U.S. Department of Agriculture prior to 1902, when he accepted a post with the Public Health and Marine Hospital Service. In large part, he appears to have done so because of his interest in hookworm and belief that it was likely present in the United States.

24. Charles Wardell Stiles, Report Upon the Prevalence and Geographic Distribution of Hookworm Diseases (Uncinariasis or Anchylostomiasis) in the United States (Washington, DC: GPO, 1903), 97.

25. Charles Wardell Stiles, "Hook-Worm Disease in the SouthFrequency of Infection by the Parasite (Uncinaria Americana) in Rural Districts," Public Health Reports 17, no. 43 (1902). 
1902- had been the operation of treatment stations and hospitals for sailors entering American ports.

Beginning in 1890, the service-a bureau of the Treasury Department, connected to the nation's system of customs houses-had gained control over the inspection of immigrants at ports of entry and also the power, when deemed necessary by the president, to attempt to control the interstate spread of cholera, yellow fever, smallpox, and plague. $^{26}$ Under legislation passed in 1893, the service slowly began to assume control of all international and interstate quarantines. ${ }^{27}$ State and local authorities, nonetheless, continued to control the quarantine at important ports into the twentieth century. Louisiana did not transfer its quarantine facilities, including the station in New Orleans, to the service until 1907. Boston, meanwhile, transferred its quarantine station to the service in 1915 . New York became the last state to fully cede its quarantine stations in $1921 .^{28}$

Beginning in 1907 a progressive group known as the Committee of One Hundred on National Health, led by Yale professor Irving Fisher, engaged in a campaign intended to persuade Congress to consolidate all of the health-related activities of the federal government under the authority of one federal bureau or cabinet-level department. ${ }^{29}$ These activities ranged widely, from implementation of the Pure Food and Drug Act of 1906 under the auspices of the U.S. Department of Agriculture to the collection of mortality statistics by the Census Bureau and the operation of Marine Hospitals by the Public Health and Marine Hospital Service.

The Surgeon General of the Public Health and Marine Hospital Service, Walter Wyman, was opposed to this effort at consolidation. ${ }^{30}$ In part, this was because it was not clear whether the service would gain a controlling role in national health-related activities or whether it would be made subordinate to another agency. The Surgeon General opposed also the creation of a "Children's Bureau" within the

26. James A. Tobey, The National Government and Public Health (Baltimore, MD: Johns Hopkins University Press, 1926), 88-89.

27. Ibid., 90 .

28. Ibid., 91; Annual Report of the Surgeon General of the Public Health Service of the United States for the Fiscal Year 1915 (Washington, DC: GPO, 1915), 127; "Government Plans Control: Will Take Over Quarantine Station, Says Report,” New York Times, February 15, 1921. "While this act did not undertake to prohibit states or municipalities from maintaining quarantine stations," James Tobey wrote of the 1893 quarantine law, "it provided that state officers might surrender local stations to the Secretary of the Treasury, who was authorized to receive and pay for them if he considered them necessary to the United States. It would probably have been impossible to pass a law prohibiting states from maintaining quarantine stations, and the best results were thus obtained by allowing the states to surrender their quarantine functions from time to time as they realized the advantages of the national system."

29. Waserman, "The Quest for a National Health Department in the Progressive Era."

30. Ibid.
Public Health and Marine Hospital Service. Wyman, public health scholar Wilson Smillie later wrote on the basis of the recollections of a close associate of the Surgeon General, was mainly concerned "with the police powers of port quarantine and with the surgical treatment of sailors." Confronted with the prospect of supervising the proposed Children's Bureau, "he was most emphatic in his refusal to complicate his life with the importunities of a group of sentimental women who were interested solely in the welfare of mothers and infants." ${ }^{31}$ The bureau-which some members of the service would later view as something of a rival-ended up as part of the Department of Labor. $^{32}$

The Committee of One Hundred and other proponents of a consolidated federal health agency, such as Senator Robert Owen (D-OK) and President William Howard Taft, were never able to fully agree on the specifics of their intended goal. They were particularly divided over the question of whether the agency should be a cabinet-level department or a bureau. As a result, the opponents of a federal health agency retained the upper hand, and the push for consolidation went nowhere. ${ }^{33}$

Surgeon General Wyman died in late 1911, but Congress embraced the limited recommendations that he had made during the debate over the creation of a national health department. ${ }^{34}$ In 1912, Congress passed legislation raising the pay of the service's commissioned officers, renaming it the Public Health Service (PHS) and, importantly, expanding its research authority. ${ }^{35}$ Under the new legislation, the PHS was granted the somewhat vague authority to "study and investigate the diseases of man and conditions influencing the propagation and spread thereof, including sanitation and sewage and the pollution either directly or indirectly of the navigable streams and lakes of the United States."

The new leader of the PHS, Rupert Blue, interpreted the authorization broadly. According to the Surgeon General's report for 1912, it marked "a new epoch in the history of the health activities of the Federal Government, and it is believed [that the Act] clearly recognizes the Public Health Service as

31. Quoted in Bess Furman, A Profile of the United States Public Health Service, 1798-1948 (Washington, DC: U.S. Department of Health Education, and Welfare, National Institutes of Health, National Library of Medicine, 1973), 279. The Wyman associate was Milton Rosenau, who played an important early role in the service's Hygienic Laboratory, the precursor of the National Institutes of Health.

32. From 1912 until the creation of the Department of Labor in 1913, the bureau was a part of the Department of Commerce. See Tobey, National Government and Public Health, 233.

33. See Waserman, "The Quest for a National Health Department in the Progressive Era," 377-78.

34. "Walter Wyman Dead: Surgeon General of the Public Health and Marine Hospital Service," New York Times, November 21, 1911.

35. Furman, Profile of the United States Public Health Service, 286. 
the central health agency in the Nation."36 Before 1912, the service's most substantial inland endeavor had been a large-scale attempt to kill plague-infected ground squirrels in the San Francisco Bay area. ${ }^{37}$ Starting in July of 1913, the PHS received an appropriation of $\$ 200,000$ "for field investigations," $\$ 47,000$ for the study of pellagra, and $\$ 20,000$ for the operation of its Hygienic Laboratory, the precursor of today's National Institutes of Health. ${ }^{38}$ In addition, Congress authorized the use of money from the PHS's "epidemic fund" to hold trachoma clinics in southern Appalachia to prevent "the spread of the disease in interstate traffic." An often-blinding eye disease, trachoma was widespread in the region. ${ }^{39}$

Despite the growth of PHS "investigations" and the novel decision (made with the approval of state departments of health) to hold trachoma clinics, state and local governments continued, fundamentally, to be left to their own devices in terms of active public health work outside of ports of entry. Unsurprisingly, the ability of local governing authorities to cope with threats to public health diverged substantially.

\section{State and Local Public Health Capacity Before World War I}

During the latter part of the nineteenth century, attempts by sanitary reformers (stressing community cleanliness and exposure to clean air and light) to respond to rapid urbanization as well as a growing knowledge of bacteriology had brought a revolution in public health first to Great Britain and then to the industrializing areas of the northern United States. As Lawrence Gostin writes, "A pervasive regulatory system evolved in state and local governments to ameliorate the health effects of industrialization and urbanization." 40

The ability to collect adequate vital statistics can stand as a bare minimum standard for assessing statelevel public health capacity. Mortality rates are, in the language of James C. Scott, a "state simplification," enabling governments to grasp "a large and complex reality... The only way to accomplish this is to reduce an infinite array of detail to a set of categories that will facilitate summary descriptions, comparisons, and aggregation." 41

36. Tobey, National Government and Public Health, 102; Annual Report of the Surgeon General of the Public Health Service of the United States for the Fiscal Year 1912 (Washington, DC: GPO, 1913), 9.

37. See "Campaign against Plague-Infected Squirrels in California," Public Health Reports 26, no. 16 (1911).

38. Furman, Profile of the United States Public Health Service, 288; Annual Report of the Surgeon General of the Public Health Service of the United States for the Fiscal Year 1912, 317, 30.

39. Annual Report of the Surgeon General of the Public Health Service of the United States for the Fiscal Year 1912, 36.

40. Gostin, Public Health Law, 151.

41. James C. Scott, Seeing Like a State: How Certain Schemes to Improve the Human Condition Have Failed (New Haven, CT: Yale University Press, 1998), 77.
In the absence of vital statistics, diseases are, for practical purposes, invisible to governments. If disease is invisible in location, in extent, and in terms of the attributes of those affected, the processes of policy development and implementation become at best extremely difficult and are unlikely to prove effective. In 1880, the U.S. Census Bureau created a Death Registration Area, consisting initially of Massachusetts, New Jersey, Washington, DC, and a number of cities throughout the United States that the bureau had confirmed were adequately recording mortality statistics. By 1909, the Death Registration Area fully encompassed eighteen states, including all nine of the northeastern states. The remaining states stretched across the Midwest and West, with Maryland the only border state certified as capable of adequately recording mortality rates. None of the states of the former Confederacy were included in the Death Registration Area. ${ }^{42}$

Southern cities, for the most part, kept pace with their counterparts in the rest of the nation. Municipal officials in the region effectively responded to important public health threats such as typhoid fever. As Werner Troesken has argued, urban public health interventions intersected with ideas about race in interesting ways. ${ }^{43}$ The dominant ideology of white supremacy might have been expected to represent a significant barrier to the implementation of health policies aimed at improving the health status of blacks. Indeed, as Evan Lieberman finds in an important comparative study, government responses to the AIDS pandemic have been heavily influenced by the extent and character of ethnic divisions within societies. In nations with strong "internal boundaries dividing societies into substantial and recognizable ethnic groups," discussions of the disease and the risk of infection from it "are infused with ideas about ethnic difference." As groups within a society attempt to assign blame and "avoid the group shame associated with a stigmatized problem, the effect is a dampening of potential support for AIDS policies, leading to weaker and slower responses." ${ }^{4}$

In the early twentieth-century South, of course, blacks had almost no political voice and little effective means of resisting attempts by whites to associate them with particular diseases or the spread of disease in general. In addition, their health status could be plausibly linked to threats to the health status of whites. In the case of typhoid, as Troesken shows, effectively combating typhoid required that southern cities not discriminate on the basis of race

42. U.S. Census Bureau, Mortality Statistics (Washington, DC: GPO), 1909.

43. Werner Troesken, Water, Race, and Disease (Cambridge, MA: MIT Press, 2004).

44. Evan Lieberman, Boundaries of Contagion: How Ethnic Politics Have Shaped Government Responses to Aids (Princeton, NJ: Princeton Universtiy Press, 2009), 3. 
in providing access to sewers and clean drinking water. ${ }^{45}$ Despite the growing rigidity and codification of racial segregation at the beginning of the twentieth century, urban blacks and whites, particularly in older southern cities, lived in relatively close proximity. Given the circumstances, typhoid among blacks could be expected to spread to whites; moreover, proximity often made it prohibitively difficult to avoid black residential areas when constructing sewer lines. ${ }^{46}$

If southern cities had largely embraced the new practices of public health growing out of the sanitary and bacteriological revolutions, the region remained overwhelmingly rural. As of the 1910 Census, the states of the Census "North" were 58.6 percent urban. The Census "West" was 48.8 percent urban. ${ }^{47}$ In contrast, the states of the Census "South" (comprised of the former Confederacy, Washington, D.C., and all border states except for Missouri) were only 22.5 percent urban. $^{48}$ In 1911, the border states of Missouri and Kentucky were admitted to the registration area. Still, by 1915 , Virginia was the only former Confederate state to have been admitted to the Death Registration Area (Figure 1).

\section{Hookworm in the Southern United States}

The least capable states in terms of public health capacity, southern states faced particularly significant public health problems.

Created in late 1909 and beginning its work in 1910, the Rockefeller Sanitary Commission for the Eradication of Hookworm made important strides toward documenting the extent of hookworm in the South and beginning to confront it. Unrecognized in the United States until Charles Wardell Stiles's work beginning in 1902, hookworm had been brought to the United States from West Africa by infected slaves. The parasite spread easily in the rural South as a result of the absence of sanitary privies and tendency of many poor southerners to go shoeless. Of the 250,680 homes surveyed by the

45. Troesken, Water, Race, and Disease. Indeed, Troesken finds that "blacks benefited more than whites, in terms of disease reduction, from investments in water and sewer lines and water purification systems" during this period. See Troesken, Water, Race, and Disease, 204.

46. Troesken, Water, Race, and Disease. See also Don H. Doyle, New Cities, New Men, New South: Atlanta, Nashville, Charleston, Mobile, 1860-1910 (Chapel Hill: University of North Carolina Press, 1990), 280-81. Doyle argues that the "democracy of disease" in urban areas caused white reformers to favor public health measures for blacks.

47. 1910 Census, 55. The Census "North" is made up of the Missouri plus all areas where slavery had been outlawed prior to the Civil War from Maine in the east to the line of plains states stretching south from North Dakota to Kansas in the west. The West is comprised of all states west of and including the line of states that stretches from Montana in the North to New Mexico in the South.

48. 1910 Census, 55.
Rockefeller Sanitary Commission (RSC) from 1911 through 1914 , fully 125,584 had no privy at all. ${ }^{49}$

Deposited in the soil by human feces, hookworms enter the body through the feet or hand and, in time, make their way to the intestines. If enough worms are present, hookworm sufferers experience chronic blood loss, leading to iron-deficiency anemia. Their skin "becomes waxy and acquires a sickly yellowish color," while they often experience pain in their joints and lower extremities, "headache, fatigue, and impotence." ${ }^{50}$

The RSC operated dispensaries - which diagnosed hookworm victims and then gave them purgatives that they could take at home to rid themselves of their worms-in eleven southern states from 1911 to $1915 .{ }^{51}$ Operating for approximately one month in individual counties within participating states, the hookworm dispensaries generated a great deal of publicity for the disease. They did not, however, bring an end to the South's hookworm problem.

Extrapolating from county-level data on hookworm incidence in schoolchildren, it is possible to calculate a rough estimate of the extent of hookworm disease in the states surveyed by the RSC. ${ }^{52}$ An estimate based on these surveys and county-level population data from the U.S. Census suggests that, of the 23,929,700 individuals living in the states in which the RSC operated, approximately 6,749,216 (28.2\%) were infected.

From 1911 through the end of 1914, only 440,376 ( $6.5 \%$ of those estimated to be infected) were given the purgative Thymol through the RSC's dispensary campaigns (Table 1). Since the treatments were administered at home, rather than under the supervision

49. The Rockefeller Sanitary Commission for the Eradication of Hookworm, Fifth Annual Report (1915),14.

50. Simon Brooker, Peter J. Hotez, Jeffrey M. Bethony, Maria Elena Bottazzi, et al., "Current Concepts: Hookworm Disease," The New England Journal of Medicine 351, no. 8 (2004): 802.

51. The eleven states were those of the former Confederacy, with the exception of Florida, and the border state of Kentucky.

52. Contemporary studies of the "American" hookworm (Necator americanus) have suggested that the disease's prevalence tends to be higher among teenagers and adults than among young children. As a result, it is possible to use the RSC's surveys of children ages 6-18 as a proxy for the entire population of a county. See D.W.T. Crompton, "The Public Health Importance of Hookworm Disease," Parasitology 121(2000): S41. Surveys were compiled from The Rockefeller Sanitary Commission for the Eradication of Hookworm Disease, Second, Third, Fourth, and Fifth Annual Reports (Washington, DC: 1911, 1912, 1913, 1914). The missing infection rates for counties that were not surveyed have been derived from neighboring counties with similar characteristics through the use of State Economic Area groups, following the SEA descriptions in Steven Ruggles; J. Trent Alexander; Katie Genadek; Ronald Goeken; Matthew B. Schroeder; Matthew Sobek, Integrated Public Use Microdata Series: Version 5.0. [Machine-Readable Database] (Minneapolis: University of Minnesota, 2010). County population data was accessed through Minnesota Population Center, National Historical Geographic Information System: Version 2.0. (Minneapolis: University of Minnesota 2011). The URL for NHGIS is http://www. nhgis.org. 

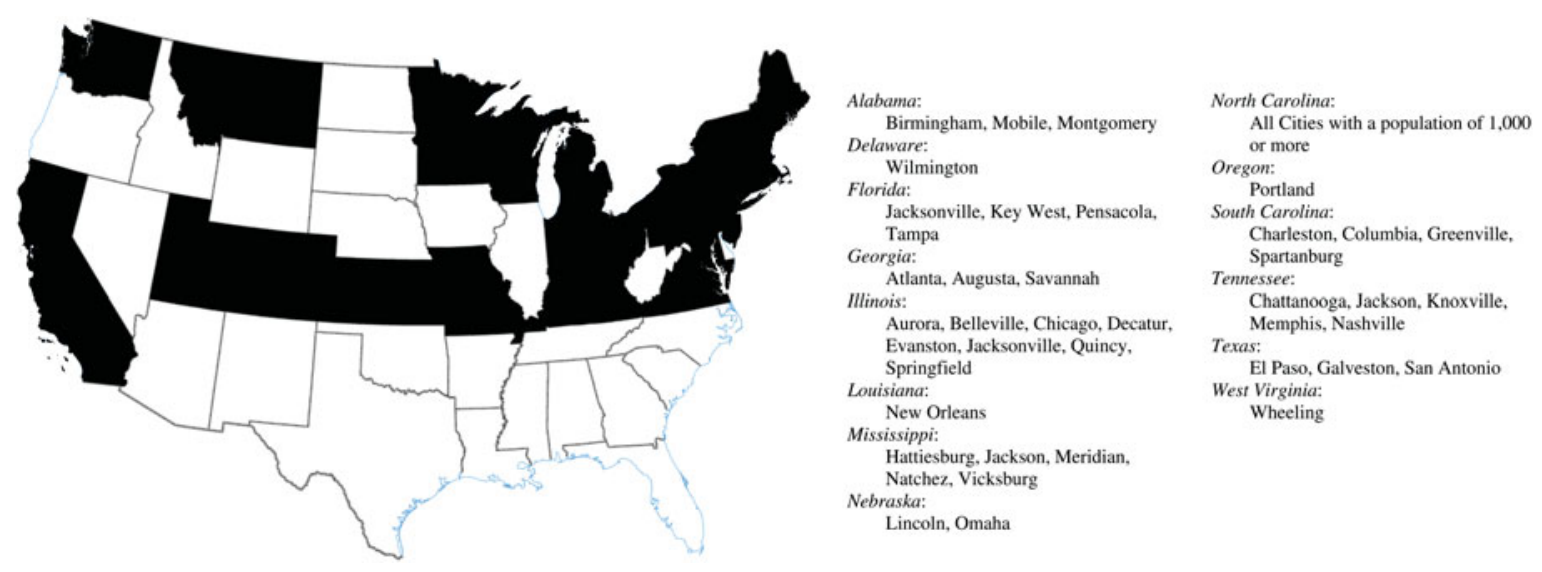

Fig. 1. The U.S. Death Registration Area in 1915. Source: Bureau of The Census, Mortality Statistics, 1915, p. 8, 10.

of field agents or physicians, it is impossible to know how many actually took the drug. Of those who did, we do not know how many succeeded in purging themselves of their hookworms. Among those who were successfully treated, the general lack of access to sanitary privies in the region likely ensured that a significant number became re-infected.

Those in charge of the Rockefeller philanthropy recognized the failings of the "dispensary" approach. It was limited by time, by the need for those who had hookworm to actually show up to be diagnosed, and by the likelihood that many would simply become re-infected if they did not build sanitary privies. Beginning in 1915, the Rockefeller Foundation's International Health Board (IHB) adopted a new approach to the health problems of the South, aimed at stimulating more sustained community interest in public health and the development of local public health infrastructure. Importantly, the IHB's program (like the earlier effort of the RSC) required that local governments provide matching funds for public health work as a means of demonstrating their commitment to the effort.

The IHB's early impact on the ability of local governments to confront disease should not be overstated. At first, it operated mainly in units below the county level. By 1917, a later study commissioned by the PHS and carried out by the Rockefeller Foundation found, the IHB was helping to fund full-time county health departments in a total of only thirteen southern counties. ${ }^{53}$

In its public health efforts, the Rockefeller philanthropy embraced and often deployed the arguments of the PHS's Charles Wardell Stiles concerning the economic impact of hookworm. "I believe that there are millions of people in our Southern States who

53. John Ferrell and Pauline Mead, Public Health Bulletin No. 222: History of County Health Organizations in the United States, 1908-33 (Washington, DC: GPO, 1936). are affected by the hookworm who can be saved," Stiles explained to the Washington Post in language characteristic of his thought on the subject. "Not saved from disease alone, but saved from that laziness which has given them the title of 'shiftless' and 'poor white trash." Hookworm, according to Stiles, "causes much of the economical poverty of the States which are infested most with the germ which produces it." 54

In focusing on the economic impact of hookworm in the South and on southern whites, Stiles argued explicitly that the disease needed to be eliminated also among blacks. Since blacks often lived and worked in close proximity to whites, ongoing hookworm infection among blacks would represent a threat to the health of whites. "It is absolutely necessary," Stiles explained in a 1908 speech to the North Carolina State Board of Health, "to avoid any distinction between the white and the negroes in this campaign of sanitary education., 55

The responsibility of white landowners to black tenants as well as to their own families, Stiles maintained, was unambiguous: "The white man who fails to recognize the important necessity of improving the sanitary conditions under which the negro is living fails to go to the root of the evil, and he unconsciously invites disease and death, especially to the women and children of his own race. ${ }^{.56}$

54. "Crusade to Transform the South's 'Poor Whites' into Industrious Citizens," Washington Post, September 27, 1908.

55. Charles Wardell Stiles, "The Medical Influence of the Negro in Connection with Anemia in the White, Address Given to the North Carolina Board of Health and State Medical Society, June 17, 1908," in Biennial Report of the North Carolina Board of Health, 1907-1908 (Raleigh, NC: 1909), 28. See also Marion Hamilton Carter, "The Vampire of the South," McClure's Magazine, October 1909, 631. Marion Hamilton Carter, relying on Stiles's work, advised the readers of McClure's that "The one real hope of curing the white man lies in curing the black man."

56. Stiles, "The Medical Influence of the Negro," 28. 
Table 1. The Extent of Hookworm Infection as Indicated by RSC County Surveys and The Total Number of Cases Recorded Treated Through Dispensary Campaigns, 1911-1914

\begin{tabular}{|c|c|c|c|c|c|}
\hline State & 1910 Population & $\begin{array}{c}\text { Estimated } \\
\text { Hookworm Victims }\end{array}$ & $\begin{array}{c}\text { Estimated } \\
\text { Percent Infected }\end{array}$ & $\begin{array}{c}\text { Cases } \\
\text { Treated }\end{array}$ & $\begin{array}{c}\text { Percentage of } \\
\text { Estimated Infected } \\
\text { Treated }\end{array}$ \\
\hline Alabama & $2,138,093$ & 868,076 & $40.6 \%$ & 43,520 & $5.0 \%$ \\
\hline Arkansas & $1,574,449$ & 268,496 & $17.1 \%$ & 6,970 & $2.6 \%$ \\
\hline Georgia & $2,609,121$ & $1,349,350$ & $51.7 \%$ & 45,494 & $3.4 \%$ \\
\hline Kentucky & $2,289,905$ & 373,720 & $16.3 \%$ & 37,916 & $10.1 \%$ \\
\hline Louisiana & $1,656,388$ & 346,358 & $20.9 \%$ & 37,225 & $10.7 \%$ \\
\hline Mississippi & $1,797,114$ & 600,059 & $33.4 \%$ & 73,919 & $12.3 \%$ \\
\hline North Carolina & $2,206,287$ & 873,335 & $39.6 \%$ & 98,990 & $11.3 \%$ \\
\hline South Carolina & $1,515,400$ & 716,218 & $47.3 \%$ & 38,411 & $5.4 \%$ \\
\hline Tennessee & $2,184,789$ & 444,121 & $20.3 \%$ & 23,332 & $5.3 \%$ \\
\hline Texas & $3,896,542$ & 548,487 & $14.1 \%$ & 17,490 & $3.2 \%$ \\
\hline Virginia & $2,061,612$ & 360,995 & $17.5 \%$ & 17,109 & $4.7 \%$ \\
\hline Total & $23,929,700$ & $6,749,216$ & $28.2 \%$ & 440,376 & $6.5 \%$ \\
\hline
\end{tabular}

Source: Adapted and calculated from the Annual Reports of the Rockefeller Sanitary Commission, 1910-1914, State Economic Areas (Following IPUMS), and the 1910 Census of Population and Housing, accessed through the National Historical Geographic Information System. See above footnote for more detailed sources and methods. Note: Numbers are rounded.

\section{Malaria}

While the Rockefeller philanthropy embarked on its campaign against hookworm disease, the PHS paid increasing attention to the nation's malaria problem. $^{7}$ Beginning in 1912, PHS officers attempted to map the domestic distribution of the disease. Two important obstacles stood in their way: the states where malaria was most prevalent were largely outside of the Death Registration Area, and the disease had a far greater impact in terms of chronic illness than in terms of mortality. The malaria-causing parasites Plasmodium vivax and Plasmodium falciparum were both endemic in the United States, but deaths were largely associated with $P$. falciparum.

The public, meanwhile, appeared to be largely indifferent to the threat of malaria, a disease that had long been known to exist in the region. As the

57. An influential account of the malaria problem in the southern United States may be found in Margaret Humphreys, Malaria: Poverty, Race, and Public Health in the United States (Baltimore, MD: Johns Hopkins University Press, 2001). Humphreys adopts a broad time horizon, encompassing the period discussed in this article, and makes frequent mention of the U.S. Public Health Service. Nonetheless, her analysis of public health efforts aimed at limiting malaria in the United States overlooks both the intervention of the federal government against malaria during World War I and the subsequent development of federally backed local public health infrastructure in the South. These are substantial oversights. As I argue below, the federal government played a central role in the demise of malaria in the United States. Quantitative support for the argument that federal public health interventions played a key role in the demise of southern malaria may be found in George Mohler and Daniel Sledge, "Eliminating Malaria in the American South: An Analysis of the Decline of Malaria in 1930s Alabama," American Journal of Public Health (forthcoming).
PHS's John Trask observed in 1916, “An exotic disease which threatens invasion or an occasional malady of which little is known will arouse a general interest, while ailments which are widely prevalent and are thoroughly understood receive the most meager attention . . Malaria is not commonly a direct cause of death and has aroused little of the interest usually associated with more obviously fatal morbid processes." 58

Malaria, Trask argued, played a substantial role in life in the southern United States and particularly in hindering the region's economic growth: "Infected individuals have their efficiency impaired as parents, as workmen, and as citizens. Infected workers lose more or less time because of the disease and are less satisfactory workmen." 59 As contemporary studies of the economic impact of malaria have made clear, the disease seriously hinders the development of human capital, impacts worker productivity, and discourages the in-migration of talented individuals. $^{60}$

By 1917, the PHS had produced detailed maps of reported malaria cases in a number of states, based on survey cards mailed to southern physicians. ${ }^{61}$

58. John W. Trask, "Malaria: A Public Health and Economic Problem in the United States," Public Health Reports 31, no. 51 (1916): 3445-46.

59. Ibid.

60. See John Luke Gallup and Jeffrey D. Sachs, "The Economic Burden of Malaria," American Journal of Tropical Medicine 64, nos. 1, 2 (2001); Jeffrey Sachs and Pia Malaney, "The Economic and Social Burden of Malaria,” Nature 415 (2002).

61. See, for instance, "Malaria in Alabama: Prevalence and Geographic Distribution-1915 and 1916," Public Health Reports 
Still, a full accounting of malaria mortality data, collected by the PHS from state health departments, would not be published until 1923 (See Figure 2). ${ }^{62}$ Plagued by debilitating disease, southern state and local governments operated largely in darkness as Europe plunged into war.

\section{FEDERAL PUBLIC HEALTH EFFORTS IN WORLD WAR I EXTRA-CANTONMENT ZONES}

American entry in World War I made the daunting public health problems of the southern United States an issue of pressing national concern. Though most essential war industries were located in the industrial North, a large number of military encampments were located in the South. As troops flooded the region, the United States Public Health Service was placed by executive order and an act of Congress in charge of "extra-cantonment zones," areas of intensive public health work surrounding military camps that "because of means of communication, transportation, origin of food stuffs, or any other factor, [have] a bearing either directly or indirectly upon the state of the health and bodily welfare of the troops."63

Beginning in July of 1917 , the PHS had a $\$ 500,000$ appropriation at its disposal for "protecting health of the military forces." In addition, a PHS program for "studies of rural sanitation," previously focused largely on surveys of the typhoid problem in rural America, was re-engineered as a means of organizing health work in extra-cantonment zones and given an appropriation of $\$ 150,000$ (up from $\$ 25,000$ ). The increased appropriation could now only be spent in communities that agreed to match expenditures from the PHS. ${ }^{64}$ By the end of the war, the PHS was operating in forty-eight extra-cantonment

32, no. 51 (1917); "Malaria in North Carolina: Prevalence and Geographic Distribution," Public Health Reports 32, no. 29 (1917); R.H. von Ezdorf, "Malarial Fevers: Prevalence and Geographic Distribution in South Carolina, Georgia, and Florida," Public Health Reports 29, no. 11 (1914); "Malaria in Eastern Texas: Prevalence and Geographic Distribution," Public Health Reports 32, no. 33 (1917).

62. Kenneth F. Maxcy, "The Distribution of Malaria in the United States as Indicated by Mortality Reports," Public Health Reports 38, no. 21 (1923).

63. See Annual Report of the Surgeon General of the Public Health Service of the United States for the Fiscal Year 1918 (Washington, DC: GPO, 1918), 103; Annual Report of the Surgeon General of the Public Health Service of the United States for the Fiscal Year 1919, (Washington, DC: GPO, 1919), 86-87. This quotation is from PHS Officer J.A. Watkins's description of the Camp Shelby Extra-Cantonment Zone in Mississippi. J.A. Watkins, "Extra-Cantonment Zone Sanitation, Camp Shelby, near Hattiesburg, Miss," Public Health Reports 32, no. 51 (1917): 2149.

64. Annual Report of the Surgeon General of the Public Health Service of the United States for the Fiscal Year 1918, 323. zones. All but nine were located in the South (Figure 3). ${ }^{65}$

The Camp Shelby Extra-Cantonment Zone, surrounding Hattiesburg, Mississippi, was typical of PHS operations in the South during World War I. ${ }^{66}$ Within the military encampment itself, the U.S. Army handled sanitation. Surrounding it, the PHS took control of a fourteen-county area with a population of approximately 239,000. ${ }^{67}$

Some basic public health work was already underway. The IHB had recently operated in some counties in the area, ensuring a pre-existing degree of administrative capacity that the PHS was able to expand upon. Forrest County, home to Camp Shelby and Hattiesburg, employed a sanitary inspector. In addition, Forrest County and Hattiesburg had "a very recently appointed part-time health officer." 68

Hookworm incidence had been reduced as a result of the IHB's work, and many of the rural communities surrounding Camp Shelby had, compared with much of the region, relatively high levels of access to sanitary privies. ${ }^{69}$ Still, active public health work remained rudimentary. Although "an admirable percentage of the registered physicians reported the cases of communicable diseases occurring in their practices, the reports were made only once a month."70

The underlying poor health of the extracantonment zone was inescapable: PHS sanitary engineer Joseph A. LePrince reported that "Malaria prevails in the area in which Hattiesburg and Camp Shelby are situated. Anopheles are easily found, and conditions at present are favorable to the spread of this disease. The situation is serious."71

The influx of civilian workers, "each with a span of mules or team of horses," into the area surrounding the military encampment compounded the preexisting situation. Overwhelming local resources, workers lived in makeshift settlements with little

65. Benjamin S. Warren and Charles F. Bolduan, "War Activities of the United States Public Health Service," Public Health Reports 34, no. 23 (1919): 1247-48. The South is defined here as the eleven former states of the Confederacy plus Kentucky and Oklahoma. The extra-cantonment zone around Washington, D.C., included parts of Virginia and is counted as southern.

66. For a summary of PHS work in all extra-cantonment zones, see Annual Report of the Surgeon General of the Public Health Service of the United States for the Fiscal Year 1918, 103-60; Annual Report of the Surgeon General of the Public Health Service of the United States for the Fiscal Year 1919, 86-106. See also Rupert Blue, "Conserving the Nation's Man Power: Disease Weakens Armies, Cripples Industry, Reduces Production. How the Government Is Sanitating the Civil Zones around Cantonment Areas. A Nation-Wide Campaign for Health," National Geographic, September 1917.

67. Watkins, "Extra-Cantonment Zone Sanitation, Camp Shelby, near Hattiesburg, Miss," 2149.

68. Ibid., 2153.

69. Ibid; Report of the Board of Health of the State of Mississippi June 1-30, 1915 (Jackson, MS/ Nashville, TN), 17, 36, 43, 47.

70. Watkins, "Extra-Cantonment Zone Sanitation, Camp Shelby, near Hattiesburg, Miss,” 2153.

71. Ibid., 2151. 


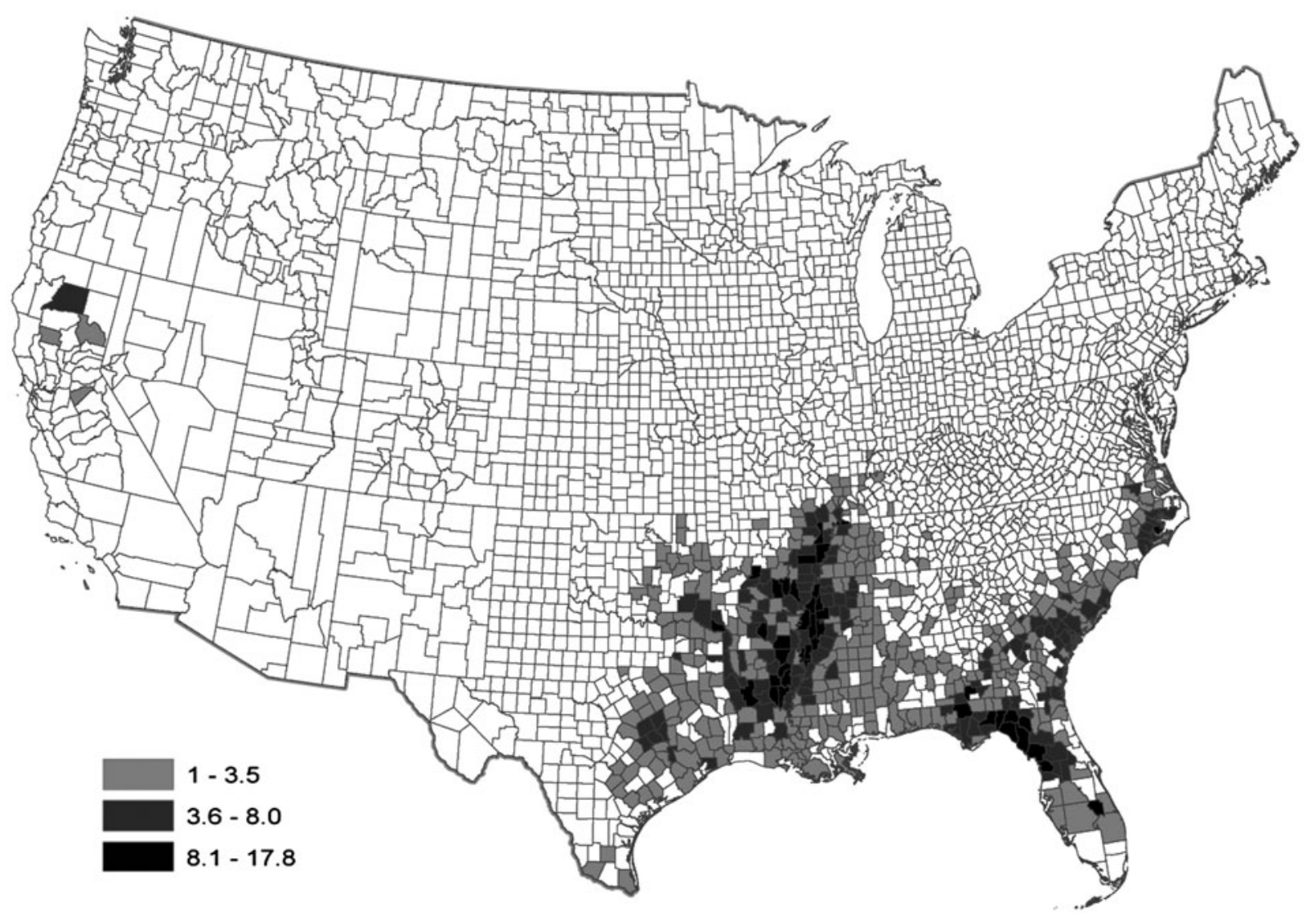

Fig. 2. Average Malaria Mortality per 10,000 in the United States, 1919-1921. Source: Adapted from Maxcy, "Distribution of Malaria in the United States." Note: Maxcy excluded counties with a mortality rate of less than 1 per 10,000 .

access to safe water or sanitary privies, presenting "a sanitary problem of major importance." In Hattiesburg, the "sudden and comparatively great increase in population ... placed so great a strain upon public utilities, such as gas, water, electricity; the sewerage, garbage, and refuse collection system; streets, public buildings, toilets, etc., that existing facilities proved entirely inadequate to meet these unusual demands." 72

Because of uncertainty about the constitutionality of federal health activities at the local level, PHS Officer J.A. Watkins was "made the legally authorized agent of the State board of health of the State of Mississippi, and, by executive action of this board, [was] delegated all legal authority possessed by the State board of health under existing laws of the State of Mississippi." ${ }^{\text {73 }}$

The arrangement was effective, but it underscored the precarious nature of the national government's authority. Legally absorbed into the public health

72. Ibid., 2153.

73. Ibid., 2149 apparatus of various states, Watkins and other PHS officers enjoyed no greater authority as agents of the federal government during wartime than as county health officers. As Samuel Grubbs, the PHS officer in charge of the Newport News-based extra-cantonment zone, later recalled, "there were apparently no plans, precedents, or instructions. 'Go talk to the Health Officer of Virginia,' I was told. Authority? 'Only what he will give you.'”74

From Hattiesburg, Watkins directed a large group of public health workers, which included two other PHS officers, Forrest County and Hattiesburg's parttime health officer, three sanitary inspectors (one from the Public Health Service), "a number of laborers and miscellaneous employees," and a sanitary unit funded by the Red Cross. The unit was "composed of 3 sanitary inspectors, 1 bacteriologist, 1 laboratory attendant, 3 public health nurses, a business manager, and 1 clerk." ${ }^{.75}$

74. See Samuel B. Grubbs, By Order of the Surgeon General (Greenfield, IN William Mitchell Printing Company, 1943), 287.

75. Watkins, "Extra-Cantonment Zone Sanitation, Camp Shelby, near Hattiesburg, Miss," 2155. 


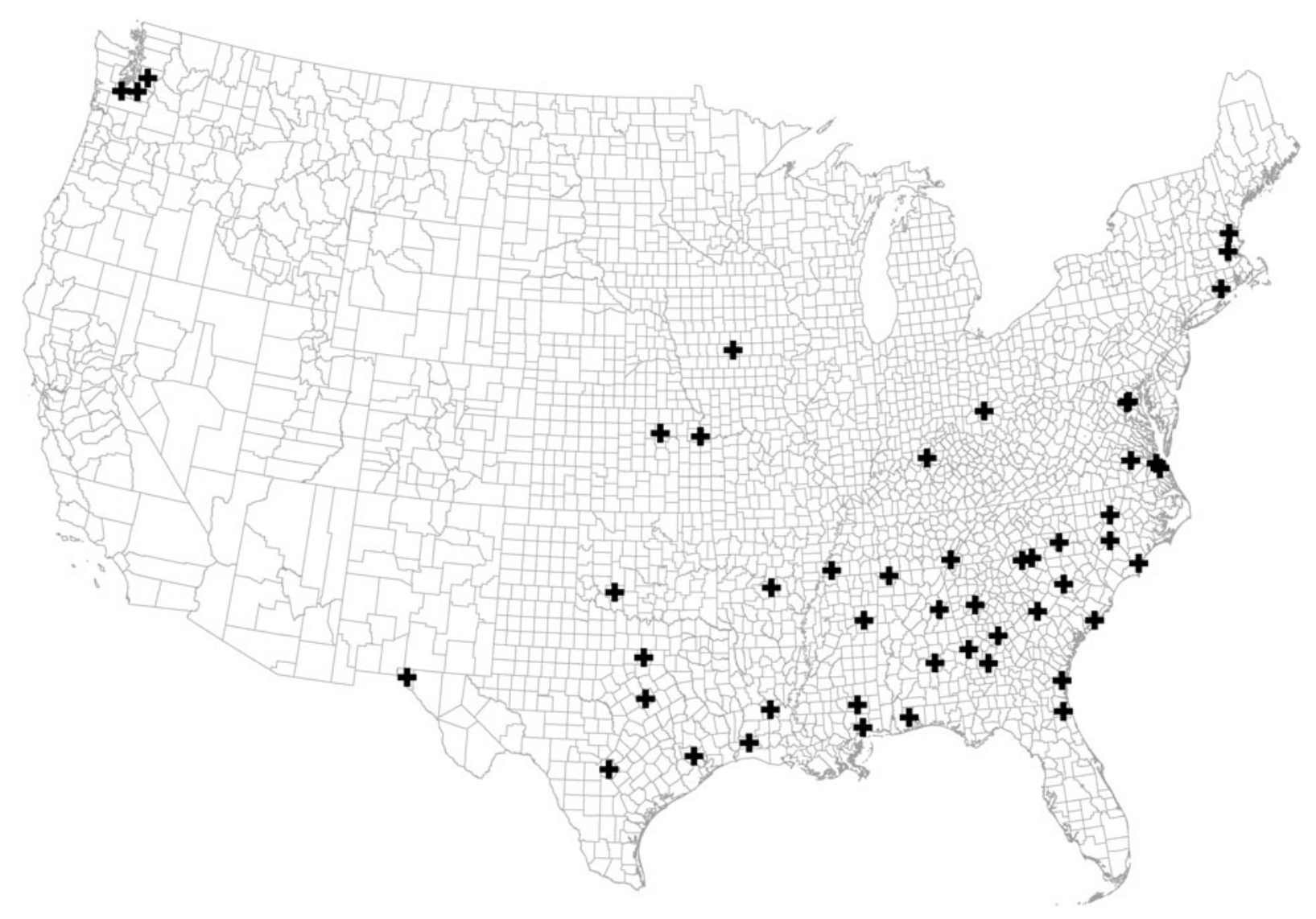

Fig. 3. Headquarters of World War I Extra-Cantonment Zones. Source: Adapted from Warren and Bolduan, "War Activities of the United States Public Health Service."

As was the case in most extra-cantonment zones, support from the Red Cross proved crucial. ${ }^{76}$ The organization appropriated $\$ 10,000$ "to be expended under the direction of the [PHS] officer in charge, for the salaries and expenses of the personnel of the Red Cross unit and the care of the indigent sick of importance from a public-health standpoint, and for the purchase of nonexpendable materials and equipment." 77

Though the resources available to him were significant, Watkins found that the legal authority granted to public health workers in Mississippi was generally weak. In Hattiesburg, there were no local "ordinances of importance pertaining to public health.” Rather than pressing for new legislation, however, Watkins decided to attempt "to obtain sanitary requirements under existing State sanitary laws."

"Work has been prosecuted with the idea of enforcing existing laws," wrote Watkins, "even though they be defective, and obtaining desired conditions by

76. Bolduan, "War Activities of the United States Public Health Service," 1246.

77. Watkins, "Extra-Cantonment Zone Sanitation, Camp Shelby, near Hattiesburg, Miss," 2155. appeal to civic pride and patriotism and by other means, rather than by the passage of numerous new laws, to which there might possibly be objection, with lack of cooperation, and of which there certainly would be much ignorance."78

As a general rule, Watkins found that the public was indifferent or resistant to public health measures. A "problem of considerable importance," Watkins wrote, "was the lack of a general public sentiment in favor of public health conditions and the absence of knowledge on the part of the community as to the necessity for the acquisition and maintenance of a rigid control and of the adoption of measures for the prevention of the spread of communicable diseases." 79

Active enforcement of public health regulations had apparently previously been minimal. When an outbreak of measles occurred, Watkins encountered an "almost universal attempt to evade requirements of the existing laws. There seemed to be a general impression that these laws having never in the past

78. Ibid., 2163.

79. Ibid., 2154. 
been enforced, it was not necessary to enforce them at the present time." 80

Public health efforts included ordering property owners to install sanitary privies, the regulation of the local milk supply (a potential source of typhoid), examinations of the water supply, free vaccination of "as many of the population of possible" against typhoid and smallpox, attempts to control venereal disease, attempts to collect vital statistics and monitor health conditions, and, of course, attempts to control malaria. ${ }^{81}$

\section{MALARIA CONTROL}

The need to control malaria was the primary reason for the concentration of wartime extra-cantonment zones in the South. Though little had been done to confront the problem of malaria in the American South before 1917, the PHS possessed much of the expertise necessary to begin controlling it in limited areas such as the extra-cantonment zones. ${ }^{82}$ Assistant Surgeon General Henry Rose Carter, a native of Virginia who had been considered for a Nobel Prize as a result of his research into the role of mosquitoes in transmitting disease, had joined the PHS in 1879, working in quarantine positions on the Gulf Coast.

Carter was sent to Cuba in 1898, where his theory of the extrinsic incubation of yellow fever influenced the work of U.S. Army medical officer Walter Reed, leader of the Yellow Fever Commission that determined that the disease was spread by mosquitoes rather than by filth. In 1904, Carter was sent to Panama, where he served "as Chief Quarantine Officer and as Chief of Hospitals until 1909." ${ }^{\text {"3 }}$

PHS Senior Sanitary Engineer Joseph A. LePrince, who oversaw the service's antimalaria efforts in extracantonment zones, had been U.S. Army General William Gorgas's "right hand" first in the control of yellow fever and malaria in Cuba and then in the Panama Canal Zone. LePrince's 1915 book, Mosquito Control in Panama, "was to remain a bible for mosquito control workers for many years."

80. Ibid., 2155 .

81. Ibid.

82. Prior to the war, PHS personnel had surveyed mosquitobreeding conditions in a few areas (often suggesting control measures) and advised physicians employed by cotton and lumber mill owners who were interested in malaria control. See Annual Report of the Surgeon General of the Public Health Service of the United States for the Fiscal Year 1915, 21-22.

83. All biographical information is from T.H.D. Griffitts, "Henry Rose Carter: The Scientist and the Man," Southern Medical Journal 32, no. 8 (1939). Griffitts, who knew Carter, reports that Carter (born in 1852) was shot in the leg during the Civil War after grabbing a gun and becoming briefly involved in an engagement with Union troops.

84. The "right hand" quotation is from the introduction, by the Department of Agriculture's L.O. Howard, of LePrince's book. See Orenstein, Mosquito Control in Panama. On LePrince's wide-ranging
If the residents of extra-cantonment zones proved reluctant to embrace expanded enforcement of public health regulations, the PHS found that local governments could generally be persuaded to cooperate in and provide financial backing for antimalaria efforts. Along Mississippi's gulf coast, Joseph A. LePrince wrote in his report on the PHS's wartime antimalaria work, "solid financial support given by the local and county authorities" helped to make "that area practically free from malaria transmission, and the local advantages of that residential area will soon be more apparent to the public at large. It is now the longest known stretch of our southern seacoast practically free from the malaria-conveying mosquito, and without doubt this far-sighted, progressive, and patriotic policy will soon pay well as a financial investment, as it has done in many instances elsewhere." 85 Southern towns, LePrince wrote, "as well as the communities in which they are located, contributed liberally toward mosquito-control measures in order to protect our military forces and make camp life pleasant for our sailors and soldiers." 86

In the Camp Shelby extra-cantonment zone, the PHS hired workers to drain mosquito-breeding areas, remove obstacles from waterways, and channel and clean ditches. "Oiling operations were carried on, using a truck on which was mounted a 200-gallon tank for the general distribution of oil, and by trained negroes supplied with knapsack sprayers." 87 The PHS's success in limiting malaria transmission during the war was significant. Antimalaria work began in August of 1917, and by 1919 Hattiesburg physicians reported an approximately 90 percent reduction of malaria incidence in the area. ${ }^{88}$ Overall, the PHS concluded that its wartime malaria-control programs resulted in the elimination of Anopheles mosquito breeding from over 12,000 square miles. ${ }^{89}$

As LePrince's comments about the potential for residential growth along the Mississippi coast suggest, PHS officials were keen to stress the potential economic benefits of their work. Corporations, according to LePrince, were "fully aware that an absence of mosquitoes has an important bearing on

career, which spanned antimalaria work from the aftermath of the Spanish-American War through the Tennessee Valley Authority, see "Leprince, Malaria Fighter," Public Health Reports 71, no. 8 (1956). 85. J.A. LePrince, "Mosquito Control About Cantonments and Shipyards," Public Health Reports 34, no. 12 (1919): 548.

86. Ibid., 552.

87. Watkins, "Extra-Cantonment Zone Sanitation, Camp Shelby, near Hattiesburg, Miss," 2157.

88. Annual Report of the Surgeon General of the Public Health Service of the United States for the Fiscal Year 1919, 92.

89. Bolduan, "War Activities of the United States Public Health Service," 1248-49. A description of the PHS's wartime antimalaria work may be found in LePrince, "Mosquito Control About Cantonments and Shipyards." 
the availability and efficiency of skilled and unskilled labor as well as on the proper development of real-estate values."

"The local chambers of commerce and the press," he continued, "now appreciate the other commercial advantages that follow mosquito eradication measures." ${ }^{90}$ In an argument quickly becoming commonplace, LePrince claimed that "it often costs a community, and the citizens of it personally, much more to support a mosquito nuisance than to eliminate it." "91 Malaria control was, above all else, an investment in the economic future of a community and even of the nation.

LePrince believed that the PHS's wartime efforts would provide a strong precedent for malaria control following the armistice, predicting that malaria control proponents might, for purely economic reasons, manage even to gain support from outside of the region. "The business interests of the North," LePrince suggested optimistically in a paper read before the Southern Medical Association's meeting in November of 1919, "will be quick to see that if we reduce malaria in the South by 100,000 or $1,000,000$ or more cases, that just so much more earning capacity (now dormant) will be created ... The Northern manufacturer will have an increased market for his products and the Northern laborer will prosper."92

\section{THE LEVER RURAL HEALTH BILL: INTERSTATE DISEASE, ECONOMIC DEVELOPMENT, AND MILITARY PREPAREDNESS}

Though brief, American involvement in World War I left a substantial domestic legacy. "In the nineteen months that passed from the declaration of war to the Armistice of November 1918, the United States drafted 2.8 million men, transported two million of them to Europe, and lost over 100,000 soldiers in combat. Federal spending increased nearly 1,000 percent, and the size of the federal bureaucracy more than doubled." 93 The war brought the recently created Federal Reserve into a central role in the American economy, made the progressive income tax "the mainstay of American federal financing," and played an important role in paving the way for

90. LePrince, "Mosquito Control About Cantonments and Shipyards," 552.

91. Ibid., 553. "The President of a large association of cottonmill interests," LePrince continued, "has stated that the elimination of mosquitoes near the mill properties has paid a higher return on the money expended than any other investment that the corporation has ever made."

92. J.A. LePrince, "The Aftermath of Malaria Control in ExtraCantonment Areas," Southern Medical Journal 13, no. 6 (1920): 414-15.

93. Porter, War and the Rise of the State, 269. the extension of voting rights to women under the 19th Amendment. ${ }^{94}$

The PHS appeared poised to emerge stronger from the war. In 1918, Congress passed the ChamberlainKahn Act, appropriating \$1 million "for each of the fiscal years 1919 and 1920 to be paid to states" to be used for venereal disease control and education (with PHS consultation), and $\$ 200,000$ for the "establishment and maintenance of the Division of Venereal Diseases in the Public Health Service."95 An "Interdepartmental Social Hygiene Board" administered the funding for state venereal disease control. Like so many other war measures, however, the funding was cut drastically following the war's end and, by 1926 , was cut entirely. ${ }^{96}$

Meanwhile, the PHS was briefly placed in charge of operating hospitals for veterans of the war, an inadequately funded mandate that PHS leaders did not relish. In 1922, President Harding transferred veterans' care by executive order to the newly created Veterans' Bureau. ${ }^{97}$ As Hugh Cumming, the Virginian appointed Surgeon General by President Wilson in early 1920, would later recall, "I had to organize as best we could out of nothing . . . the hospitalization of the ex-service men after the World War. President Harding saw fit to make them separate, much to my relief, I might say, and set up a different organization." 98

As the war came to an end, PHS officers perceived an opportunity to retain and perhaps even expand the PHS's wartime involvement in active public health work. Over the course of the war, the PHS had engaged in an unprecedented degree of cooperation with state and local governments, greatly expanding its involvement in public health efforts beyond the nation's ports. Wartime movement of troops and civilian populations, along with the need to quickly establish partnerships between local officials, the Public Health Service, and the Red Cross, had exposed clear weaknesses in the existing system. The "Spanish" influenza pandemic, ongoing during the winter of 1918-19, further strengthened arguments for coordination between state, federal, and local authorities.

94. Ibid., 270, 274; Saldin, War, the American State, and Politics since $1898,69-70,78$.

95. The first quotation is from Tobey, National Government and Public Health, 136. The second quotation is from C.C. Pierce, "Public Health Service Program for Nation-Wide Conrol of Venereal Disease," Public Health Reports 34, no. 20 (1919): 1057.

96. Tobey, National Government and Public Health, 136.

97. Furman, Profile of the United States Public Health Service, 345.

98. Economic Security Act: Hearings before the Committee on Ways and Means, House of Representatives, Seventy-Fourth Congress, First Session, on H.R. 4120, a Bill to Alleviate the Hazards of Old Age, Unemployment, Illness, and Dependency, to Establish a Social Insurance Board in the Department of Labor, to Raise Revenue, and for Other Purposes (Washington, DC: GPO, 1935), 329. 
With the backing of the American Public Health Association (and in particular its president, North Carolina's Watson Rankin), the American Conference of State and Provincial Health Authorities, and a few sympathetic members of Congress, PHS officers offered a strong critique of the overall lack of coordination in American public health. "It seems essential at this time," outgoing Treasury Secretary William Gibbs McAdoo, President Wilson's son-in-law and the Surgeon General's immediate superior, wrote Wilson on November 21, 1918, in a letter signaling the PHS's postwar hopes, "that the Federal Government assume some measure of leadership in aiding and stimulating States, counties, and municipalities in improving their sanitary conditions, especially as the Public Health Service in its work of supervising sanitary conditions in extra cantonment and industrial areas has greatly extended and crystallized its experience in the best measures for improving the sanitary conditions of communities." He continued, "While the war has revealed the deplorable conditions of the public health and has accentuated the need of corrective measures, these conditions have not changed since the signing of the armistice, and the need for their correction is just as great, if not greater than ever." 99

On December 3, 1918, the PHS presented its plan for an expanded postwar federal presence in public health to the Congress. Relying on the PHS's experience in coordinating with local officials during the war, the most ambitious part of the plan called for "Federal aid extension for establishment and maintenance of adequate county health organizations," dependent on a matching funds formula similar to that already being used by the Rockefeller International Health Board, which required state and local governments to provide funding for the development of public health infrastructure.

Federal expertise would be employed in the development of county health practices, and, following the pattern of legal integration of federal and state roles adopted during the war, the county health officer would be appointed "as field agent of the Public Health Service at [a] nominal salary.” The rudiments of an integrated national public health system, resting on county health boards, would be built from the bottom up. The PHS would act as an initial source of funding, a source of practical expertise, and a clearinghouse for state and national health data. ${ }^{100}$

In Congress, South Carolina Representative Asbury "Frank" Lever (D-SC), the chairman of the House Agriculture Committee, was eager to expand upon

99. B.S. Warren, "Coordination and Expansion of Federal Health Activities,” Public Health Reports 34, no. 49 (1919): 2772, reprint of letter from Secretary McAdoo to President Wilson, originally sent November 21, 1918.

100. Annual Report of the Surgeon General of the Public Health Service of the United States for the Fiscal Year 1919, 18. wartime sanitary improvements in his home state and to continue the flow of federal resources into the South. Within weeks of the armistice, he was in touch with Watson Rankin, the president of the American Public Health Association, and officers from the Public Health Service. Following the PHS's December 3 proposal, Lever introduced a bill that embodied the PHS plan for federal grants-in-aid in support of county health work. ${ }^{101}$

A driving force behind the 1914 Smith-Lever Agricultural Extension Act, which "provided for a 'cooperative' effort between the federal government and state land-grant universities to carry practical scientific information about farming and home economics to farm families," Representative Lever embraced the PHS's contention that the lack of public health capacity in rural America could be addressed through a similar cooperative program. ${ }^{102}$ His proposed Rural Health Act would authorize an initial appropriation of $\$ 250,000$ for cooperative health work, which would in time grow to $\$ 1$ million a year. ${ }^{103}$ The federal government's role in protecting health in the wartime extra-cantonment zones, if the Lever Bill passed, would be expanded into a permanent role in the development of county health services.

Attempting to justify the creeping expansion of the PHS's activities and persuade Congress to support their plans for the federally backed development of local public health infrastructure in the rural United States, PHS officers emphasized the "interstate" nature of disease, the retarding economic effects of endemic disease, and the impact of ill health on the ability of the nation to raise an army in time of war. An expanded mandate for federal public health activities, they maintained, was constitutionally unobjectionable.

Assistant Surgeon General Benjamin Warren, speaking in favor of greater federal, state, and local cooperation before the Birmingham, Alabama, Civic League in January of 1919, noted the massive advances in knowledge of how to limit disease that had been made in the past two decades. It was, he

101. See Rural Sanitation: Hearings before the Committee on Agriculture of the House of Representatives, Sixty-Fifth Congress, Third Session, February 17, 1919 (Washington, DC: GPO, 1919); Warren, "Coordination and Expansion of Federal Health Activities," 2767; Annual Report of the Surgeon General of the Public Health Service of the United States for the Fiscal Year 1919, 18. The Lever Bill was introduced on December 12, 1918.

102. This description of the Smith-Lever Act is from Elizabeth Sanders, Roots of Reform: Farmers, Workers, and the American State, 1877-1917 (Chicago: University of Chicago Press, 1999), 392. Lever's attitude toward federal power and money is neatly summarized in a statement quoted by Sanders: "When there is a great general good to be accomplished by legislation, I am not so squeamish about the Constitution."

103. Rural Sanitation: Hearings before the Committee on Agriculture of the House of Representatives, Sixty-Fifth Congress, Third Session, February 17, 1919, 8. 
asserted, "hardly necessary to tell an Alabama audience that Gorgas, Carter, and their assistants made the Panama Canal possible ... Of more recent data, and nearer home, is the health work which protected the soldiers in the camps of this country during the mobilization of millions of men." Describing the extent of cooperation between the PHS, military authorities, state and local governments, and the Red Cross, Warren suggested that the results of antimalaria efforts in the civilian areas around military camps "may well be compared with those in Panama, especially since they were obtained not under military conditions, but through the voluntary work of a civil population." 104

It seemed evident that federal, state, and local cooperation should continue: disease was an interstate matter, inherently of interest to the federal government. "A case of typhoid fever in a remote rural district of Alabama," Warren told the Birmingham audience, "is a matter of joint interest to the county, State, and Federal health authorities. The typhoid germ does not recognize county or State lines and may find its way into intra and interstate traffic and cause the loss of many human lives and the expenditure of large sums of State and Federal funds." The nation's disorganized public health activities, he concluded, needed to be more fully integrated. "The rational procedure would be to form the partnership [of county, state, and federal health agencies] and prevent or control all preventable diseases at the source." 105

In February of 1919, PHS officers appeared before the House Committee on Agriculture, chaired by Congressman Lever, to discuss the merits of the Lever Rural Health Bill. Assistant Surgeon General J.W. Shereschewsky began by detailing the appropriateness of federal intervention. "It is evident, so far as rural health conditions are concerned" he told the committee, "that these are something which not only concern localities themselves, but concern the State governments, concern the Federal government, and concern every man, woman, and child in the United States."

104. B.S. Warren, "A Unified Health Service," Public Health Reports 34, no. 9 (1919): 378.

105. Ibid., 381. See also, for example, Rural Sanitation: Hearings before the Committee on Agriculture of the House of Representatives, SixtyFifth Congress, Third Session, February 17, 1919, "Statement of Dr. J.W. Schereschewsky, Assistant Surgeon General of the United States Public Health Service," 11-12; "Malaria: A Serious Health Problem of Nation-Wide Concern," Public Health Reports 34, no. 12 (1919): 544; Testimony of Dr. Leslie Lumsden, Rural Sanitation: Hearings before the Committee on Interstate and Foreign Commerce of the House of Representatives, Sixty-Fifth Congress, Third Session, on H.R. 3549, December 10, 1918 (Washington, DC: GPO, 1918), 28; L.L. Lumsden, Public Health Bulletin No. 94: Rural Sanitation: A Report on Special Studies Made in 15 Counties in 1914, 1915, 1916 (Washington, DC: GPO, 1918), 17-18; Warren, "Coordination and Expansion of Federal Health Activities,” 2769.
The reason, according to Shereschewsky, was that "our existence ... is dependent, in the last analysis, upon the food production of the rural sections. For this reason the status of the rural health is not a status which simply affects the rural people, but inasmuch as rural health conditions affect national production, it inevitably follows that the conditions of rural health are intimately tied to the prosperity of the entire Nation."106

Pioneered by the PHS's Charles Wardell Stiles and by the Rockefeller Sanitary Commission in its efforts against hookworm, the economic rationale for public health measures gained additional prominence as a result of the apparent positive economic impact of antimalaria programs in the wartime extracantonment zones. Getting rid of disease, PHS officers confidently explained, would more than pay for itself through improvements in worker productivity. "It may be safely stated," Assistant Surgeon General Warren maintained, "that if Alabama would free itself from malaria the increase in the taxable values of the State would meet all the expenses." 107

Surgeon General Rupert Blue, speaking before the December 1918 meeting of the American Public Health Association, explained that "the continued prevalence" of malaria "in large sections of the country is not only deplorable but interferes, to an extent but little appreciated, with the economic development of the nation." 108 The PHS was well-prepared to deal with the problem, having had "splendid training in anti-malarial work during the past two years."

Leslie Lumsden, the Virginian who had overseen the use of the PHS's appropriation for "rural sanitation" for wartime extra-cantonment work and who was expected to be placed in charge of the funding provided by the Lever Rural Health Act, also emphasized the economic impact of disease in his appearance before Lever's House Agriculture Committee. "A man with chronic malaria, though able to keep going, only goes at half speed ... The annual economic loss in this country from malaria and typhoid fever alone has been estimated at $\$ 900,000 . " 110$

The economic loss from hookworm disease, Lumsden told the committee, was difficult to estimate: "There are so many cases we do not know of. Persons are affected, a little below par, pulled down a little, anemic, incapacitated but able to keep

106. Rural Sanitation: Hearings before the Committee on Agriculture of the House of Representatives, Sixty-Fifth Congress, Third Session, February 17, 1919, 11-12.

107. Warren, "A Unified Health Service," 379.

108. Rupert Blue, "Urgent Public Health Needs of the Nation," American Journal of Public Health 9, no. 2 (1919): 98.

109. Ibid., 102.

110. Rural Sanitation: Hearings before the Committee on Agriculture of the House of Representatives, Sixty-Fifth Congress, Third Session, February 17, 1919, 31 . 
going at a reduced rate. The economic loss from hookworm is tremendous." 111

Data collected by the PHS gave weight to the claims of PHS officers. "Recent surveys in the South," a PHS report found in March 1919, "show that the crop yield by plantations where malaria prevails is only a fraction of what it normally should be. Just at the time when the crops need most attention, chills and fever keep a large number of laborers from work." Meanwhile, according to the report, the presence of malaria in large parts of the South deterred white settlement: "There is practically no instance known," the PHS concluded, "of a white community thriving where malaria seriously prevails."112

Beyond the apparent dire economic effects of disease, the military draft had made clear the effects of ill health on the nation's military preparedness. The PHS's plan for its own postwar expansion, as presented to Congress, placed this issue front and center. The urgency of the nation's health problems, the proposal's introduction plausibly maintained, was "indicated by the fact that in the recent draft over 34 per cent of all registrants were rejected by examining boards on account of physical defects and diseases."113

Speaking in May 1919, Lumsden summarized both the scope of the problem and the rationale for federal intervention by tying together rural health, the health of the nation, and military preparedness: "The cross section of our health conditions, furnished by the physical examination of the draftees, presents evidence which should be convincing even to the most obtuse that we-and by 'we' I mean the individual, the community, and the local, State, and National Governments-have seriously and fearfully neglected the most important factor in our national development-our human power." Poor sanitary conditions in the rural areas of one state, Lumsden explained,

are, through commerce and otherwise, a menace to contiguous States especially; and, on account of modern transportation facilities, a menace to the whole country. Having such an important bearing on the character of farm products shipped from one State to others, and having such an important bearing on the ability of our whole Nation to raise and maintain armies for the common defense, the problem of rural sanitation appears to be one with which the National Government under constitutional authority may deal, and one

111. Ibid.

112. "Malaria: A Serious Health Problem of Nation-Wide Concern," 545 .

113. Annual Report of the Surgeon General of the Public Health Service of the United States for the Fiscal Year 1919, 17. On hookworm disease and the draft, see also The Rockefeller Foundation International Health Board, Fifth Annual Report, January 1, 1918-December 31, 1918 (New York, 1919). with which the National Government from a standpoint of general welfare should deal. ${ }^{114}$

\section{FAILURE OF THE LEVER BILL AND USE OF THE APPROPRIATION FOR "RURAL SANITATION"}

It appeared at first that the Lever Rural Health Bill had a strong chance of becoming law. Watson Rankin, head of the North Carolina State Board of Health and the president of the American Public Health Association, easily persuaded the association to endorse the bill at its December 1918 annual meeting. In January, he sent instructions to each state health officer in the nation for helping to ensure that the legislation was passed.

State health officers were asked to lobby their elected representatives either in person or through the mail, to persuade prominent citizens to write their senators and representatives, to gain the support of farm demonstration agents and farmers' organizations and ask them to lobby their political representatives, and to "inform and interest the leading papers of the State in this bill."115

Congressman Lever, Rankin wrote in a statement on the bill sent along with the instructions for helping to get it passed, "has taken a leading, I might say initial, part in federal aid extension legislation. He is an experienced legislator, and an expert in legislation directed to the rural interests." Rankin concluded that " $[\mathrm{t}]$ he prospects for this bill passing Congress during its present session are exceptionally bright." ${ }^{116}$ For his part, Surgeon General Rupert Blue also contacted state health officers, forwarding copies of the Lever Bill and requesting that they ask their state legislatures for appropriations for rural health work "contingent upon the appropriation of a similar amount by the federal government."117

Despite an apparently positive hearing before the Agriculture Committee in February, however, the Lever Bill did not move quickly through Congress.

114. Printed version of lecture delivered May 22, 1919, in New York City.

115. "Program for each state health officer for assisting in the enactment of bill providing for rural health work," included with form letter to state health officials from W.S. Rankin, January 21, 1919. National Archives, College Park, MD. Records of the Public Health Service (RG 90), Central File, 1897-1923. 2240 (January 1918-January 1919), Box 219.

116. "Statement," included with form letter to state health officials from W.S. Rankin, January 21, 1919. National Archives, College Park, MD. Records of the Public Health Service (RG 90), Central File, 1897-1923. 2240 (January 1918-January 1919), Box 219

117. Oscar Dowling, President of Louisiana State Board of Health, to Surgeon General Rupert Blue, January 21, 1919. See also for instance W.H. Kellogg, Secretary of the California State Board of Health, to Rupert Blue, January 24, 1919; S.J. Crumbine, Secretary of the Kansas State Board of Health, to Rupert Blue, January 24, 1919. All in Records of the Public Health Service (RG 90), Central File, 1897-1923. 2240 (January 1918-January 1919), Box 219. 
The Republican Party had won control of the Congress in the November midterms, and a new Congress was sworn in in March of 1919. Congressman Lever, as a result, was no longer chairman of the Agriculture Committee.

Still anticipating the bill's passage, PHS officers did what they could to keep their relationships with state and county governments alive. Using money from the $\$ 150,000$ wartime appropriation for "studies and demonstrations in rural sanitation," Leslie Lumsden and his subordinates continued to pursue cooperative projects in what were still termed "extra-cantonment zones" into 1919. ${ }^{118}$

In general, reports from the field remained optimistic. From the Charleston, South Carolina, extracantonment zone, W.H. Slaughter wrote that the local Chamber of Commerce was "taking steps to see that $\$ 5,000.00$ be appropriated by the County of Charleston to meet a like sum of money put up by the Government, to carry on rural sanitation work in the County of Charleston." ${ }^{119}$ From the Brunswick, Georgia, zone, created only in August of 1918, M.V. Ziegler reported that the Glynn County commissioners had "agreed to turn over to the Board of Health convict labor to institute proper draining provided the service of a Sanitary Engineer could be secured from the U.S. Public Health Service in this capacity."120 In Virginia, the PHS's Warren F. Draper was working in concert with the State Board of Health and the State Council of Defense to extend and expand PHS extra-cantonment work. $^{121}$

There were, nonetheless, signs that local governments might not continue funding public health work without federal support. Harrison County, located on Mississippi's gulf coast, had initially been at the far reaches of the Camp Shelby extracantonment zone. In March of 1918, it became part of a new coastal zone encompassing the area around Gulfport, Biloxi, and Pass Christian. The county board of supervisors decided to fund a fulltime health officer at the end of 1917, but began to reconsider this decision a year later in light of low

118. See Hearings before Subcommittee of House Committee on Appropriations in Charge of Sundry Civil Bill for 1919 (Washington, DC: GPO, 1918), 248.

119. W.H. Slaughter to Surgeon General, In Re: Appropriation for Rural Sanitation Work, Charleston County, February 1, 1919; "At the Chamber: To A County Fund For Health Work," Charleston Evening Post, January 31, 1919. National Archives, College Park, MD. Records of the Public Health Service (RG 90), Central File, 1897-1923. 2240 (January 1918-January 1919), Box 219.

120. M.V. Ziegler, Medical Officer in Charge, to the Surgeon General, April 16, 1919. National Archives, College Park, MD. Records of the Public Health Service (RG 90), Central File, 1897-1923. 2240 (January 1918-January 1919), Box 219.

121. L.L. Lumsden to Surgeon General (requesting that a qualified officer be detailed to assist Draper), April 19, 1919. Records of the Public Health Service (RG 90), Central File, 1897-1923. 2240 (January 1918-January 1919), Box 219. county funds and the end of the war, deciding to hold an election in order to determine whether they should continue funding a full-time officer.

Leslie C. Frank, the PHS sanitary engineer in charge of the Mississippi Coastal District, believed it "was a foregone conclusion, in view of the relatively large number of prosecutions which had been made during the year in bringing about the sanitary reform" that "those voters who felt a grievance . . . would be sure to come to the polls and vote "nay." The voters who had complied with sanitary regulations, Frank believed, "would be insufficiently interested to come out and vote at all."

Having worked closely with the county health officer, Frank attempted to intervene. After conferring with the head of the state department of health, he "wrote an open letter to the citizens and voters of Harrison County, which was published in the local paper and mailed to all the voters."122 Addressing Harrison County's "shrewd voters," "successful business men," and "modern farmers," Frank described local improvements in sanitation and malaria control, pointing out that the long-term presence of the PHS in the area was not at all guaranteed. $^{123}$

Nonetheless, the "disgruntled" voters who participated in the low-turnout election rejected the continuation of a full-time health officer, and "the Board of Supervisors reduced the salary of the Health Officer from $\$ 3600$ to $\$ 2400$ per year." At this point, Frank contacted the PHS Bureau headquarters in Washington, ultimately succeeding in his efforts to have the Harrison County public health officer appointed a field agent of the PHS and given a $\$ 1,200$ salary through the PHS's "rural sanitation" program. ${ }^{124}$

As the months wore on, there was still no word from Washington that the Lever Bill, reintroduced in the new Republican Congress, had been passed. In June, the nation's state and territorial health officers came to Washington for their annual conference with the Surgeon General. Watson Rankin, urging state

122. Leslie C. Frank to Surgeon General, February 10, 1919. National Archives, College Park, MD. Records of the Public Health Service (RG 90), Central File, 1897-1923. 2240 (January 1918-January 1919), Box 219.

123. Undated letter (December 1918) from Leslie C. Frank, Director of Sanitation, Mississippi Coastal District, United States Public Health Service. National Archives, College Park, MD. Records of the Public Health Service (RG 90), Central File, 1897-1923. 2240 (January 1918-January 1919), Box 219. "WHAT GUARANTEE HAVE YOU," Frank wrote in capital letters, "of the length of stay of the Public Health Service in its constructive and policing capacity?"

124. Leslie C. Frank to Surgeon General, February 10, 1919. National Archives, College Park, MD. Records of the Public Health Service (RG 90), Central File, 1897-1923. 2240 (January 1918-January 1919), Box 219. L.L. Lumsden, "Cooperative Rural Health Work of the Public Health Service in the Fiscal Year 1920," Public Health Reports 35, no. 40 (1920): 2330. 
health officers to meet with their political representatives while in Washington, told them that, as a result of the attention brought to health conditions by the military draft, "the country is more receptive to suggestions for improving sanitary and hygienic conditions at this time that at any other." 125

Both Rankin and the PHS's Leslie Lumsden urged the state health officers to support also the PHS's request to Congress that, if the Lever Bill was not passed, the existing appropriation for "rural sanitation" be expanded from $\$ 150,000$ to $\$ 500,000$. "In case the Lever bill should fail to pass," Rankin told the health officers, "our only chance is in getting through this appropriation of $\$ 500,000$ which is contained in the sundry civil bill." 126

As the health officer of the state of Massachusetts informed his fellow officials, however, politicians from heavily urbanized states had little incentive to support federal efforts directed at rural health problems: "To be perfectly frank between ourselves, there are some States that are not financially benefited by this act." Though some members of the Massachusetts congressional delegation had informed him they would either support or not oppose the bill, "others have come out very frankly and flatly said they were getting rather tired (to use the exact phrase that one Congressman used) of having \$2 of Massachusetts money taken out of the taxpayers of Massachusetts, about 25 cents of it returned in the form of Federal aid, and the rest distributed over the South, the West, and the Middle West." ${ }^{\text {"127 }}$

In Atlantic City for the Conference of State and Provincial Health Authorities of North America a few days later, Rankin continued to maintain that the Lever Rural Health Bill had "splendid prospects of passing, provided the members of this organization will make it a matter of personal responsibility and get in touch with their senators and congressmen." ${ }^{128}$ In July, however, Representative Lever was appointed by President Wilson to fill a vacant position on the

125. If the Public Health Service and State Boards of Health did not "take hold of this matter and direct," he warned them, "it is going to come through some other channel; and it is going to be our fault if some other organization-the Department of Agriculture, for example ... the Red Cross, or some other organizationtakes hold of this matter and drives it through and fixes it up according to its own ideas." Public Health Bulletin No. 105: Transactions of the Seventeenth Annual Conference of State and Territorial Health Officers with the United States Public Health Service, Held at Washington, D.C. June 4 and 5, 1919, (Washington, DC: GPO, 1920), 14.

126. Ibid., 16, 23. "The other way to get immediate action on a reasonably adequate scale," Dr. Lumsden told the assembled health officers, "is to get enacted or appropriated the item for rural sanitation contained in the sundry civil bill."

127. Ibid., 16.

128. Proceedings of the Thirty-Fourth Annual Meeting of the Conference of State and Provincial Health Authorities of North America, Held at Atlantic City, N.J., June 6-7, 1919 (Concord, NH: The Rumford Press, 1919), 17.
Federal Farm Loan Board, effectively ending any remaining hope that the Lever Bill would become law. $^{129}$

Meanwhile, passage of the Sundry Civil Bill for Fiscal Year 1920, containing the "rural sanitation" appropriation, was delayed long enough that Lumsden and his subordinates found it difficult to plan for even a limited continuation of their wartime efforts. When the bill was finally passed, in July, it became evident that PHS expansion into cooperative rural health work was slated to become a victim of postwar retrenchment. The appropriation for "studies in rural sanitation," which had stood at $\$ 150,000$ during the war, and which Lumsden had at one point imagined might be raised as high as $\$ 500,000$, was reduced to only $\$ 50,000$. $^{130}$

"On account of the reduction in the appropriation," an irritated Lumsden wrote, "the work in a considerable number of areas in which it was yielding excellent results had to be discontinued." ${ }^{131}$ Nonetheless, receiving any appropriation was something of a victory. The end of the war and absence of an unambiguous mandate, such as passage of the Lever Rural Health Bill, from Congress, cast some doubt on the legitimacy of the PHS's ongoing rural health work.

As the health officer from Massachusetts had suggested, the PHS efforts had a distinctly regional emphasis. The appropriation for "studies of rural sanitation," first made available in 1916, had been intended initially to fund surveys of conditions in

129. "Resignation of Herbert Quick from Federal Farm Loan Board- Representative Lever Named as Successor," The Commercial and Financial Chronicle, a Weekly Newspaper Representing the Industrial Interests of the United States, vol. 109, July 19, 1919, 224; Official Congressional Directory, for the Use of the United States Congress, 66th Congress, 2nd Session, Begining December 1, 1919 (Washington, DC), iii. Lever was appointed to the position on July 17, 1919, and officially resigned from Congress on August 1.

130. Annual Report of the Surgeon General of the Public Health Service of the United States for the Fiscal Year 1919, 52; Lumsden, "Cooperative Rural Health Work of the Public Health Service in the Fiscal Year 1920," 2334. On June 24, 1919, only a few days before the end of the fiscal year, Surgeon General Rupert Blue and Assistant Surgeon General J.W. Schereschewsky appeared before the Senate Appropriations Committee, requesting $\$ 150,000$ for rural sanitation rather than the $\$ 50,000$ allowed by the House. The committee appeared indifferent. After being warned that "we have a list of engagements and ask you to be as brief as possible," Blue and Schereschewsky made extremely brief statements, although Schereschewsky managed to mention both the interconnection between rural communities and the rest of the nation and the economic impact of malaria. They received only one question, from Senator Reed Smoot, a well-known opponent of federal expansion in the field of public health: "You want $\$ 150,000$ instead of $\$ 50,000$ ?" See Hearings before the Subcommittee on Appropriations, United States Senate, Sixty-Sixth Congress, First Session, on H.R. 6176, a Bill Making Appropriations for Sundry Civil Expenses of the Government for the Fiscal Year Ending June 30, 1920 and for Other Purposes (Washington, DC: GPO, 1919), 25-26.

131. Lumsden, "Cooperative Rural Health Work of the Public Health Service in the Fiscal Year 1920,” 2334. 
rural areas throughout the nation. ${ }^{132}$ Under the direction of Lumsden, the appropriation had been used to continue surveys first undertaken beginning in 1914 and encompassing seven counties in the former Confederacy, four in the border states, and four in the Midwest. ${ }^{133}$

The primary reason for the emphasis on the South, border states, and Midwest was Lumsden's interest in the problem of typhoid fever in rural America (Figure 4). Though the disease continued to represent something of a threat to public health throughout the nation, advances in sanitary practices and in the quality of urban public health work had increasingly rendered it a disease of the nation's more isolated rural communities.

Lumsden had been involved in the PHS's research into typhoid since 1906. In 1911, he was dispatched to North Yakima, Washington, "to investigate typhoid fever in that city and vicinity." 134 After an investigation that lasted a little more than a month, Lumsden appeared before local government officials to advise them of the causes of typhoid in the area and to suggest potential remedies. Among the recommendations made was the creation of a full-time county health department.

At the time, many county governments paid physicians small amounts to provide care for the indigent, jail inmates, and others on a part-time basis. Outside of urban areas, however, dedicated full-time health departments were essentially nonexistent. Embracing Lumsden's advice, Yakima County was among the first governmental units covering largely rural and small town areas in the United States to provide its inhabitants with a full-time local health department. $^{135}$

Lumsden's interest in typhoid, a disease largely spread through contact with human feces, fit nicely with the work of the PHS's Charles Wardell Stiles, the discoverer of southern hookworm who was, at the time, serving as the scientific secretary for the Rockefeller Sanitary Commission. Along with Stiles and the PHS's Norman Roberts, Lumsden helped to design the "L.R.S." sanitary privy, which became the model for privy

132. The appropriation was $\$ 25,000$ for the 1917 fiscal year (beginning July 1, 1916). See Annual Report of the Surgeon General of the Public Health Service of the United States for the Fiscal Year 1917 (Washington, DC. GPO, 1917), 335.

133. Counties were surveyed in Alabama (2), Georgia (1), Illinois (1), Indiana (1), Iowa (1), Kansas (1), Maryland (2), Mississippi (1), Missouri (1), North Carolina (1), South Carolina (1), Tennessee (1), and West Virginia (1). See Lumsden, Report on Special Studies in 15 Counties.

134. Annual Report of the Surgeon General of the Public Health and Marine Hospital Service of the United States for the Fiscal Year 1911 (Washington, DC: GPO, 1911), 27.

135. On the significance of the work in Yakima from the perspective of Lumsden, see Mead, Public Health Bulletin No. 222: History of County Health Organizations in the United States, 1908-33, $2-4$. construction employed by the Rockefeller Sanitary Commission for the Eradication of Hookworm, the International Health Board, and by state health boards. $^{136}$

Following American entry into the war, the appropriation for studies of "rural sanitation" (administered through the PHS's Scientific Research Division) had been transformed into a means for pursuing cooperative programs almost exclusively in southern extra-cantonment zones. ${ }^{137}$ A firm believer in the importance of full-time rural health work since the earlier 1910s, Lumsden had embraced the opportunity to pursue the implementation of his ideas during the war and was eager to continue doing so in its aftermath.

As it turned out, he would have far less latitude in doing so than anticipated. The Lever Rural Health Bill did not become law. Though the PHS had asked for a $\$ 500,000$ appropriation for studies of rural sanitation, Lumsden received instead only $\$ 50,000$. At best, Lumsden's Office of Rural Sanitation possessed a vague mandate from a largely indifferent Congress. Still, the PHS had not been forced to completely abandon the rural health efforts pioneered during the war.

\section{PROGRAM OPERATION}

Beginning in July 1919, the PHS devoted its first postwar "rural sanitation" appropriation to funding cooperative work in thirty-one counties. As in the case of Lumsden's earlier surveys and the PHS's wartime extra-cantonment efforts, the regional tilt of the program was unmistakable: twenty-six of the counties were located in the former Confederacy, two in Missouri, and one each in Kansas, Kentucky, and Oklahoma. ${ }^{138}$

Along with the $\$ 50,000$ allotted by Congress, the Office of Rural Sanitation had "about $\$ 9,000$

136. Norman Roberts, L.L. Lumsden, and Charles Wardell Stiles, "Preliminary Note on a Simple and Inexpensive Apparatus for Use in Safe Disposal of Night Soil," Public Health Reports 25, no. 45 (1910).

137. The only nonsouthern "rural sanitation" cooperative program undertaken during the war was in Polk County, Iowa, during the 1918 fiscal year. A cooperative effort was also initiated in Mason County, Kentucky, which was not within an extracantonment zone. See Rural Sanitation: Hearings before the Committee on Agriculture of the House of Representatives, Sixty-Fifth Congress, Third Session, February 17, 1919, 14, 15. Questioning Surgeon General Rupert Blue and Assistant Surgeon General J.W. Schereschewsky in the summer of 1918, South Carolina Representative James Byrnes noted that the appropriation for rural sanitation did not appear to be being used for its original purpose: "Then, you have really abandoned the idea of investigating the questions of rural sanitation, and have been using this fund in extra-cantonment work?" See Hearings before Subcommittee of House Committee on Appropriations in Charge of Sundry Civil Bill for 1919, 248.

138. Jasper County, MO, Cherokee County, KS, and Ottawa County, OK, were part of a "tri-state" sanitary district. 


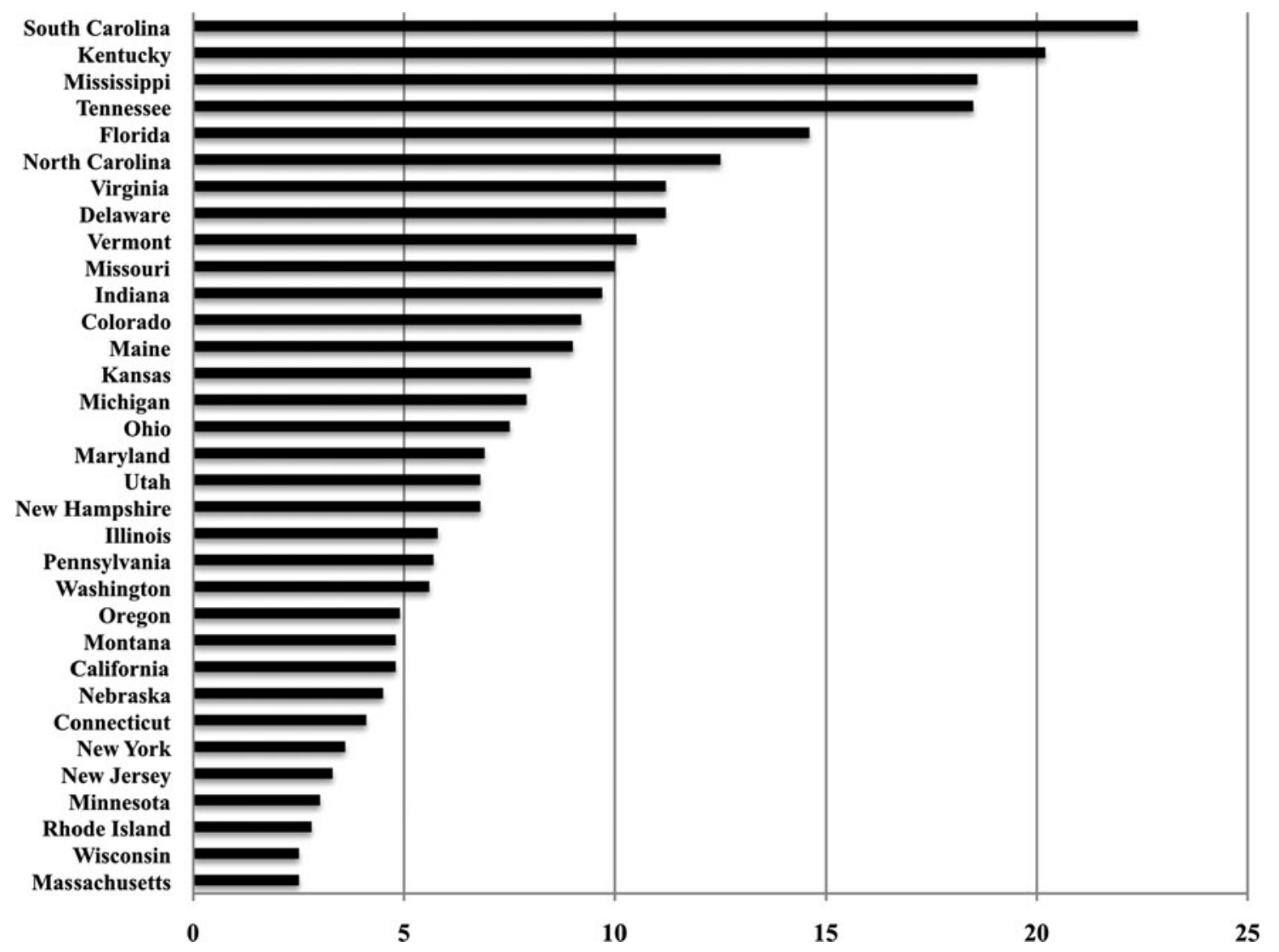

Fig. 4. Death Rates from Typhoid Fever per 100,000 in 1920 (Death Registration States Only). Source: Census Bureau, Mortality Statistics, 1920, p. 21.

unexpended under previous contracts" to dedicate to the program. County and state governments put up an additional $\$ 175,093$, while "civic sources, such as local health associations, Red Cross chapters, and the [Rockefeller] International Health Board" provided approximately $\$ 54,000$ to back up the PHS's work. ${ }^{139}$

As these figures suggest, Lumsden and those working under his Office of Rural Sanitation were not averse to requesting support from private organizations. Money from the Red Cross had played an important role in the PHS's wartime work, and the Office of Rural Sanitation would continue working with the Rockefeller International Health Board into the 1930s.

In the years before the 1927 Mississippi flood, the number of full-time county health departments receiving funds from both the PHS and the International Health Board (IHB) peaked at a high of thirty-five in 1922 (out of a total of sixty-one PHS-supported counties). Though the PHS organized the work in these counties, IHB money predominated in the counties where both agencies

139. Lumsden, "Cooperative Rural Health Work of the Public Health Service in the Fiscal Year 1920,” 2334. contributed. After 1927, PHS funding would dominate Rockefeller money in county health departments where both agencies contributed. ${ }^{140}$

PHS officials had long been dismissive of the Department of Labor's Children's Bureau. In 1921, the PHS opposed the Sheppard-Towner Act, which provided grants-in-aid to states aimed at funding health efforts for mothers and children. Surgeon General Hugh Cumming, who would later play a role in Congress's decision to discontinue the Sheppard-Towner program, sat on the Federal Board of Maternity and Infant Hygiene, which gave him a degree of influence over the decision "to approve or disapprove of State plans for the use of [Sheppard-Towner] funds." 141 His opposition to the program appears to have stemmed largely from a belief that the underqualified Children's Bureau was infringing inappropriately into the field of

140. In 1927, for instance, both organizations contributed toward full-time health departments in eighty-eight counties, fifty-eight of which were dominated by PHS money. Following the 1930-1931 drought, the PHS eclipsed the IHB as the leading organization in development of county public health infrastructure. See Figure 6.

141. Furman, Profile of the United States Public Health Service, 349. 
public health. If funding for maternal and child health was to be made available by Congress, it should be controlled by the PHS. ${ }^{142}$

For his part, Lumsden appears to have had few qualms about county health departments receiving funds from whatever sources were at hand. Organizations such as the Children's Bureau, he wrote, tended to realize "after practical experience, the advantage of dovetailing their specific activities with and making them a part of a well-rounded comprehensive program of local official health service under the immediate direction of a qualified, wholetime local health officer." ${ }^{143}$ The number of full-time county health departments receiving funding from both the PHS and the Children's Bureau peaked at twenty (out of a total of 142 counties operating with PHS support) in 1927 (Figure 5). ${ }^{144}$

County health work began with attempts by PHS officers under Lumsden's command, working with the approval of the state board of health, to secure local financial support. PHS officers would visit a county, meet with prominent citizens, and then appear before the county commissioners (or local equivalent) to attempt to persuade them of the importance of county health work and to secure an appropriation.

Warren Draper, in charge of rural sanitation work in Virginia, explained that it was important "to discuss the matter with the more enlightened citizens, and get them to come up and appear before the [county board of] supervisors." Early in his work, Draper had attempted to drum up enthusiasm for a county health department by gaining the support of residents from a part of one rural county who he had been warned were "ignorant and are satisfied to remain so." After listening to Draper's pitch, during which he asked them to attend the next meeting of the county supervisors and tell them "just what you think of what I said," a number of these citizens ("the most disreputable looking specimens of humanity that I have ever seen") appeared at the meeting. As Draper later recounted it, they loudly opposed the creation of a county health department, informing the supervisors that they believed Draper was only interested in riding "up and down the county in an

142. Ibid., 350; Theda Skocpol, Protecting Soldiers and Mothers: The Political Origins of Social Policy in the United States (Belknap Press of Harvard University Press: Cambridge, MA, 1992), 517.

143. L.L. Lumsden, "Cooperative Rural Health Work of the Public Health Service in the Fiscal Year 1930," Public Health Reports 45, no. 43 (1930): 2619-20. Lumsden's comments are specifically in reference to the Red Cross, Rockefeller Foundation, and the Children's Bureau. His general point is that public health work should not be divided into separated categories such as "typhoid fever prevention, hookworm control, tuberculosis prevention, trachoma control, malaria control, venereal disease prevention, school hygiene, or advancement of child and maternity hygiene."

144. Mead, Public Health Bulletin No. 222: History of County Health Organizations in the United States, 1908-33.

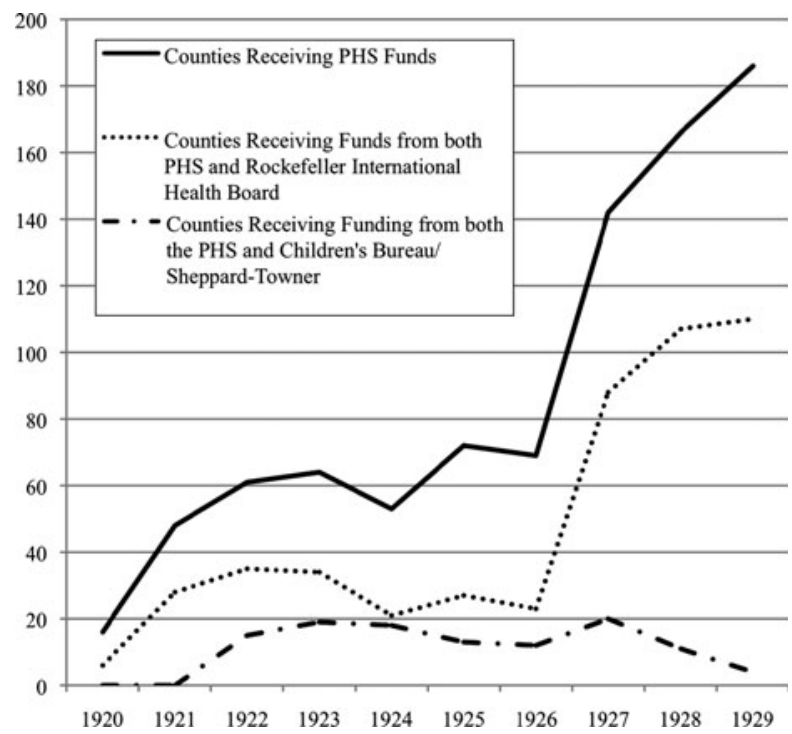

Fig. 5. Cooperation with other agencies during the 1920s. Full-time county health departments receiving backing from the Public Health Service During the 1920 s, full-time county health departments receiving funding from both the PHS and IHB, and full-time departments receiving funding from both the PHS and the Children's Bureau. Source: Adapted from Ferrell and Mead, "History of County Health Organizations."

automobile while we are paying for it with the sweat of our brows." Following this, Draper reported, his faith in democracy was weakened, and he began focusing on the cultivation of support among local elites. ${ }^{145}$

Once the support of a county government was secured, a PHS representative or representative of the state board of health would conduct a survey of local sanitary conditions. After assessing the situation, the nascent county health board began implementing health measures developed by the PHS in an order suited to the particular circumstances of the county. Though it varied by location, county work included "safeguarding of water and food supplies, sanitary excreta disposal, fly control, antimalarial measures, infant hygiene, school inspection, antituberculosis and antivenereal disease measures, [and] industrial hygiene."146

Publicity and outreach to local elites were crucial to the development of a successful county health department. Along with giving public lectures, public health

145. Public Health Bulletin No. 105: Transactions of the Seventeenth Annual Conference of State and Territorial Health Officers with the United States Public Health Service, Held at Washington, D.C., June 4 and 5, 1919, 26-27.

146. Lumsden, "Cooperative Rural Health Work of the Public Health Service in the Fiscal Year 1920," 2335; L.L. Lumsden, "Cooperative Rural Health Work of the Public Health Service in the Fiscal Year 1921,"Public Health Reports 36, no. 40 (1921): 2481. 
workers actively enlisted the support of local ministers, teachers, and influential citizens. Newspapers were asked to print articles on sanitation and editorials written in the names of local notables, while religious leaders were asked to include in their sermons messages of support for community cooperation with public health work. Health bulletins, detailing measures that could be taken to prevent the transmission of disease, were mailed to both tenants and property owners. ${ }^{147}$

A full-time county health officer, usually recruited from within the cooperating state (and ideally as locally as possible), headed all of the PHS-supported cooperative county health efforts; the officer's staff typically consisted of a full-time sanitary inspector and nurse. ${ }^{148}$ Following the precedent set during the war, county health officers were "given a status of field agent in the Public Health Service and ... a status of deputy State health officer." "Thus," Lumsden explained, "his position is an example of common-sense coordination of the administrative features of the activities of the properly constituted local, State, and National governmental health agencies." ${ }^{\text {"149 }}$

This also meant that county public health officers would have franking privileges (allowing them to, among other things, ask local residents or physicians to mail fecal and blood specimens to them or to state laboratories without charge) and would be "allowed to use Public Health Service stationary." 150 As long as the counties and states consented to the agreement, federal, state, and local public health authority would be functionally consolidated and any uncertainty about the proper limits or constitutionality of federal intervention in local public health matters could be brushed aside.

The men under Lumsden's immediate command during the first few years of the rural sanitation program included several future leaders of the PHS. Warren F. Draper, in charge of operations in Virginia, would be made of head the PHS's Division of Domestic

147. See, for example, H.S. Mustard, "Outline of Rural Health Administration in Rock-Bridge County, Virginia," Public Health Reports 35, no. 40 (1920).

148. In most counties, the health officer was a physician. In some counties, however, the health officer was not a physician, but rather a trained sanitarian.

149. Lumsden, "Cooperative Rural Health Work of the Public Health Service in the Fiscal Year 1920," 2335.

150. W.K. Sharp (Office of Field Investigations, Rural Sanitation) to Surgeon General, July 10, 1919. Records of the Public Health Service, Central File, 1897-1923. 2240 (February-May 1919) Box 220. Lumsden describes the use of franking by "field agents" in a 1926 memo to the Surgeon General written following the objection of an Alabama postmaster to Field Agent J.A. Hill's furnishing of "penalty envelopes or labels to private physicians for the purpose of enabling the latter to transmit in the mails free of postage" bacteriological specimens. See J.H. Hill to L.L. Lumsden, June 21, 1926, L.L. Lumsden to Surgeon General via W.F. Draper, June 26, 1926. Records of the Public Health Service. General Subject File, 1924-1935. State Boards of Health. Alabama 0620-2323, Box 377, NC-34, E-10, NWCH, HM 1999.
Quarantine in 1923. Thomas Parran, Jr., in Tennessee and Alabama during the war and now stationed in Missouri, would later serve as Surgeon General under Presidents Roosevelt and Truman. Joseph Mountin, stationed first in Missouri and then in Tennessee, would later head the Division of Domestic Quarantine and its successor the Division of States Relations, working with Parran to found the CDC.

The rural sanitation program soon expanded beyond the South and border states and into the rural Midwest and West. By January 1927, rural health work was being carried out in eighteen states. Along with work in the South and border states, efforts were underway in California (two counties and one health district), Iowa (one county), Kansas (three), Montana (two), and New Mexico (eight). In an attempt to determine whether the county-based form of organization employed by the PHS could be successfully adapted to governing institutions in New England, public health workers under the direction of Lumsden also helped, beginning in 1921 , in the development of local public health infrastructure on Cape Cod. ${ }^{151}$

Lumsden, who had been considered for the position of Surgeon General in 1920, would head the Office of Rural Sanitation until the end of 1930. In that year, Surgeon General Hugh Cumming promoted Lumsden, apparently contrary to his own wishes, to a position in charge of the PHS supervisory district headquartered in New Orleans. ${ }^{152}$ In 1923, Lumsden's former subordinate Warren Draper was made an assistant surgeon general and placed in charge of the Division of Domestic Quarantine. In the same year, the rural sanitation program was transferred to that division. The move from "Scientific Research" to "Domestic Quarantine" represented an important victory for Lumsden's interpretation of the legal and constitutional basis of the rural sanitation effort.

Throughout the 1920s, Lumsden articulated an expansive rationale for the efforts of his Office of Rural Sanitation to promote the development of local public health infrastructure. Above all else, he maintained, federal intervention represented the most realistic means of preventing the interstate spread of disease. "To undertake sanitary control of traffic and travel by inspection and quarantine at our city borders and on our interstate lines [under present conditions of transportation and travel],"

151. L.L. Lumsden, "Cooperative Rural Health Work of the Public Health Service in the Fiscal Year 1927," Public Health Reports 42, no. 42 (1927). The Cape Cod project, wrote Lumsden, "is of especial interest in that it furnishes a test of the applicability of the general plan of cooperative rural health work to the conditions of local government by town units obtaining in Massachusetts and other New England States." See L.L. Lumsden, "Cooperative Rural Health Work of the Public Health Service in the Fiscal Year 1922,” Public Health Reports 37, no. 39 (1922): 2362.

152. See Furman, Profile of the United States Public Health Service, 370 . 
Lumsden argued, "would be futile and ridiculous. The efficient local health department, in doing its local work, performs a duty of state-wide and nationwide importance with which the State and Federal health services are concerned."153

In addition to confronting the problem of interstate disease at its root, Lumsden noted that the efforts of his office could be understood as investigative under the PHS's broad 1912 research authorization. For good measure, he maintained that though "very limited as yet in extent, it does contribute to that essential part of the work of the Federal Government to promote the general welfare." Operating only with the consent of state and local authorities, the program did not infringe upon the police power of the states. It did, however, strengthen the nation's military preparedness. "About 30 per cent of persons of military age," Lumsden wrote, "are incapacitated for arduous productive labor or for general military duty." In addition, health work would result in "economic saving," meaning both less money spent fighting epidemic disease and a generally more productive population. "The saving in dollars and cents," according to Lumsden, amounted to "many times over the cost of the service."154

\section{DEVELOPMENT OF MALARIA CONTROL TECHNIQUES}

The PHS's investigations into the screening of tenant homes during this period shed some light on the confluence of technical and social challenges that the service confronted and on the sources of its later success. By the 1920s, PHS sanitary engineers had extensive experience in controlling the spread of malaria in limited areas such as the Panama Canal Zone and the wartime extra-cantonment zones. Dealing with the presence of endemic malaria throughout wide parts of the rural South, however, represented a far vaster problem.

Screening windows, many PHS officials believed, was a potentially powerful means of limiting transmission of the malaria parasite in areas where attempting to control mosquito breeding through drainage might prove prohibitively difficult or expensive. ${ }^{155}$ The often poor quality construction and irregular measurements of southern tenant homes, however, appeared to present a significant obstacle. ${ }^{156}$ Meanwhile, whether sharecroppers and

153. L.L. Lumsden, "Cooperative Rural Health Work of the Public Health Service in the Fiscal Year 1929," Public Health Reports 44, no. 49 (1929): 2987.

154. Lumsden, "Cooperative Rural Health Work of the Public Health Service in the Fiscal Year 1920," 2383-84.

155. See, for instance, D.L. Van Dine, "The Destruction of Anopheles in Screened Dwellings," Southern Medical Journal XIV, no. 4 (1921): 20.

156. James Agee offers a telling description of an Alabama tenant home: "The walls, and shutters, and floors, are not by any means solid: indeed, and beyond and aside from any amount of tenant farmers would be receptive to screening their homes and then maintaining the screening remained, for public health workers, an open question. Leading figures in the study of malaria expressed doubt that blacks could be trusted to maintain screens. ${ }^{157}$

Field experiments, however, soon demonstrated the workability of screening as a preventive measure. In spring 1924, the PHS's C.P. Coogle, serving as the county health officer in Leflore County, Mississippi, under the direction of the PHS's small Memphisbased malaria field office, discussed the likely response of tenants to a screening initiative with more than fifty large landowners in the Mississippi Delta.

Coogle encountered widespread skepticism: "It appears to be a common opinion among the planters that farm-tenant families will not take care of screens, that they willfully destroy the screens, and that proper interest in the care of screening, at least by the general run of tenants, is not to be expected. Little encouragement was derived from these interviews." He concluded that " $[\mathrm{t}]$ he planters have had experience with screening on a small and expensive scale, and their belief in its inefficiency is widespread and firmly fixed."158

Despite this response, Coogle initiated a small-scale study of the effectiveness of screening, intended to assess whether screening could be economically implemented and whether southern tenant farmers could be relied on to participate in screening measures and then perform screen upkeep. Conducted on an increasingly large scale beginning in 1924, Coogle's detailed analysis of the practicality of screening allowed the PHS some insight into the potential responsiveness of both plantation owners and rural black and white tenant farmers to a concerted effort to screen the South.

In an area like the Delta, it would be important to gain the support of large landowners. Their incentives, Coogle reported, were straightforward.

laborious caulking, they let in light in many dozens of places. There are screens for no windows but one, in the rear bedroom. Because in half the year the fever mosquitoes are thick and there are strong rainstorms, and in the other half it is cold and wet for weeks on end with violent slanted winds and sometimes snow, the right front room is not used to live in at all and the left front room is used only dubiously and irregularly . . . ." See James Agee and Walker Evans, Let Us Now Praise Famous Men (New York: Houghton Miflin, 1988, originally published 1941), 153.

157. See, for instance, the comments of D.L. Van Dine and J.A. LePrince at the 1920 meeting of the Southern Medical Association, contained in Dine, "The Destruction of Anopheles in Screened Dwellings."

158. C.P. Coogle, "Preliminary Report of Screening Studies in Leflore County, Miss.," Public Health Reports 42, no. 15 (1927). See also Annual Report of the Surgeon General of the Public Health Service of the United States for the Fiscal Year 1925 (Washington, DC: GPO, 1925), 23. 
"Planters," he explained in his report on the screening demonstration, "are business men, and it must be realized that they are not in the farming business to accommodate the tenants. The tenants are on the plantations to supply the labor, and the tenant house is for the purpose of keeping the labor close to the crop." 159

Since the planter "often appeared to be more concerned about the gnats and flies pestering his mules," than about the welfare and comfort of his tenants, it seemed unlikely that humanitarian appeals would carry much weight. More realistically, he suggested, "One can always expect the planter to be on the alert and ready to invest in screening if it can be shown to be to his advantage." Collecting accurate data on the effectiveness of screening and its impact on "the actual savings in man hours of labor, which is the essential unit of measurement on which the planter bases his profits and losses," Coogle argued, would likely prove the most effective means of mobilizing southern landowners to support any large-scale effort to screen the homes of tenant farmers.

Despite the preconceptions of both landowners and public health workers, Coogle found that black tenant farmers were eager to participate in screening efforts. "The investigations," he reported, "indicated that negro tenants readily acquire an interest in and desire for mosquito protection, and, generally speaking, a large percentage of them would do the work effectively themselves if they thoroughly understood what it was for, and if they could get the screening materials." He concluded, offering an explanation for black participation, that "[t]he colored tenant is largely guided by the plantation manager."

White tenants, he reported, were more reluctant to participate. The "white tenant," Coogle wrote with some condescension, "thinks he can plan his own destiny and often finds he is mistaken." As a result of this attitude, he believed, whites were more likely to leave the plantation at the end of the season. Moreover, the "white tenant also usually complains more about his housing conditions than does the negro tenant. The latter seems to be more appreciative of his screens and takes better care of them than does the white tenant under similar circumstances."

Far from rural blacks being resistant to screening efforts, as Coogle had apparently expected, it was whites who might prove to be a problem: "The negro looks forward to having his home inspected, and it is not difficult to teach him to repair minor breaks in the screens. The white tenant is usually

159. Coogle, "Preliminary Report of Screening Studies in Leflore County, Miss.," 1105. more delinquent about repairs and often seems to be slightly resentful of house inspections. He would rather tell about the screens while at a distance from the house than have the conditions of the screens inspected on the premises."160

Already by December 1925, the PHS felt confident enough in Coogle's findings to report that "Experiments recently conducted by the service indicate that colored farm tenants can be induced to take excellent care of the screening of their homes."161 By early 1927, Coogle had developed detailed plans for inexpensively constructing screened doors, for screening windows, for plugging cracks in the floors of tenant homes and preventing the entrance of mosquitoes by plastering walls with newspaper, and for persuading landowners to support screening efforts. By appealing to the economic interests of landowners, the health concerns of tenants, and showing that screening could be done both effectively and inexpensively, Coogle's work suggested, public health workers could make significant headway in combating malaria.

\section{EXPANSION OF FEDERAL INTERVENTION IN THE AFTERMATH OF THE 1927 FLOOD}

In the spring of 1927, following a period of heavy rain, a massive flood overtook the lower Mississippi Valley. The flood covered 27,000 square miles, putting "as much as 30 feet of water over lands where 931,159 people" previously lived. ${ }^{162}$ In the aftermath of the flood, the knowledge, practical experience, and infrastructure that the PHS had developed over the preceding decade became of immediate and critical importance. Still under the direction of Leslie Lumsden, the federal-state-county cooperative program that had developed out of the wartime extra-cantonment zones emerged as the institutional basis and model for federal efforts to tame the public health catastrophe resulting from the social and economic dislocations caused by the flood.

As the magnitude of the disaster in the lower Mississippi Valley became clear, the PHS coordinated its response with Secretary of Commerce Herbert Hoover, who had been dispatched to the flood zone by President Coolidge, the American Red Cross, the Rockefeller International Health Board, and state and county boards of health. The Red

160. Ibid., 1107.

161. Annual Report of the Surgeon General of the Public Health Service of the United States for the Fiscal Year 1925, 24.

162. John M. Barry, Rising Tide: The Great Mississippi Flood of 1927 and How It Changed America (New York: Simon and Schuster, 1997), 285. 
Cross set up 149 camps for displaced individuals and families in Arkansas, Illinois, Kentucky, Louisiana, Mississippi, Missouri, and Tennessee, while state boards of health and the Rockefeller Foundation provided medical and other emergency relief personnel. ${ }^{163}$ The PHS, meanwhile, assigned twenty-four medical officers, eight sanitary engineers, and five "scientific assistants" to the flood zone. ${ }^{164}$

The PHS's Joseph A. LePrince, veteran of Havana, Panama, and the extra-cantonment zones, was asked to formulate a plan for coping with the health threats emerging from the disaster. In an initial memo, he stressed the importance of clean water, sanitary privies, and (embracing the work of C.P. Coogle in LeFlore County) effective screening.

"Where homes are apparently unfit to screen," LePrince advised, "paste newspaper or other paper on inside walls. The negroes can do this work well and such homes can be made mosquito proof." Blood-engorged mosquitoes found inside of homes in the morning should be swatted, and plantation owners should be made to understand that "the situation is serious ... Typhoid, Dysentery, and Malaria may so delay or prevent gathering of farm crops as to create a financial fiasco for farm tenant and plantation owner." 165

LePrince was at first distressed to find that "[a]pparently the Red Cross has no conception of what the real rural problem is." An inadequate response to the emerging public health threats in the region from the Red Cross, he worried, would compromise both his reputation and that of the PHS. The public, LePrince warned PHS head of malaria investigation L.L. Williams, had been led by the Red Cross to conclude that the organization's health program "has the approval of the U.S. Public Health Service and ... they are receiving the assistance of J.A. LePrince." $" 66$

Despite his initial concerns, the Red Cross quickly embraced and financed the implementation

163. One function of these camps was to ensure that local black laborers would not leave for work elsewhere. Writes James Cobb: "The national guardsmen charged with camp security appeared to have the dual mission of keeping refugees in and others-particularly labor agents-out." James C. Cobb, The Most Southern Place on Earth: The Mississippi Delta and the Roots of Regional Identity (New York: Oxford University Press, 1992), 123. See also Foster Rhea Dulles, The American Red Cross: A History (New York: Harper \& Brothers, 1953), 272.

164. J.G. Townsend, "The Full-Time County Health Program Developed in the Mississippi Valley Following the Flood," Public Health Reports 43, no. 20 (1928): 1200-1.

165. J.A. LePrince, "Suggested Plan for Sanitary Control at Flood Area Plantations and Farm Tenant Homes," Records of the Public Health Service. General Subject File, 1924-1935. Closed Stations: Virginia. Richmond Malaria Investigation-Richmond Relief Station. Box 354, NC 34, E-10, NWCH, HM 1999.

166. J.A. LePrince to L.L. Williams, Jr., May 19, 1927. Records of the Public Health Service. General Subject File, 1924-1935. Closed Stations: Virginia. Richmond Malaria Investigation-Richmond Relief Station. Box 354, NC 34, E-10, NWCH, HM 1999.
LePrince's plan, centered on the identification and screening of homes where malaria carriers lived. Within a period of approximately ninety days, PHS engineers under the supervision of LePrince were able to screen nearly seven thousand homes, helping to deny Anopheles mosquitoes access to malaria carriers and significantly limiting the intensity of the outbreak. ${ }^{167}$

C.P. Coogle's Leflore County screening study, the PHS noted, "has been the deciding factor in determining the type of malaria relief to be carried out in the recently flooded area. The only practicable scheme of widespread malaria control over a large area in times of emergency must be screening. Except for the [Leflore County study], it would have been thought impossible to use this method of control in large-scale relief work effectively and at a sufficiently reasonable cost." 168

In addition, as a result of research by the PHS's Joseph Goldberger, brewer's yeast, which contains pellagra-preventing niacin, was distributed throughout the flood zone. It was expected that the destruction of crops and drowning of milk cows would make it difficult for many living in the flood zone to eat an adequate diet. ${ }^{169}$

The crowning achievement of the PHS's intervention in the area flooded by the Mississippi River was the rapid extension of the cooperative plan for developing full-time county health departments throughout the flood zone. In spring 1927, only 18 of the 103 flooded counties in six states had full-time county health departments. Their worth, however, appeared to have been proven by their performance in the aftermath of the flood.

According to Leslie Lumsden, who was far from a neutral observer, full-time county health officers "as a rule, performed with remarkable promptness and

167. Townsend, "The Full-Time County Health Program Developed in the Mississippi Valley Following the Flood," 1200-1. See also William Deklein, "Recent Health Observations in the Mississippi Flood Area," American Journal of Public Health 18, no. 2 (1928): 148.

168. Annual Report of the Surgeon General of the Public Health Service of the United States for the Fiscal Year 1927 (Washington, DC: GPO, 1927), 39. See also C.P. Coogle, "Methods and Costs of Screening Farm Tenant Homes in Mississippi: Post Flood Malaria Control," Southern Medical Journal (1928). On the significance of Coogle's work, see also L.L. Williams, Medical Officer in Charge, Office of Malaria Investigations, to Dr. Felix J. Underwood, Mississippi State Health Officer, May 27, 1929. Records of the Public Health Service, General Subject File, 1924-1935. State Boards of Health. Mississippi, 0115-1340, Box 416, NC-34, B-10, NWCH, HM 1999. "We have seen his results spread into many of the counties of the South where identical work is being done very successfully," wrote Williams, "we saw most of the past flood emergency malaria control work carried on exactly according to the results of Dr. Coogle's work in LeFlore County."

169. Paul DeKruif, Hunger Fighters (New York: Harcourt, Brace and Company, 1928), 365-66; Townsend, "The Full-Time County Health Program Developed in the Mississippi Valley Following the Flood," 1206. 
efficiency in the organization of working forces and in the carrying out of measures for both immediate and post-flood sanitary protection of the stricken people." The difference between these counties and those without health departments with a full-time officer, he claimed, "stood out sharply."170

J.H. O'Neil, the Louisiana State Board of Health's sanitary engineer, concluded similarly that "the value of the full-time county organization . . . had been strikingly demonstrated during the flood."171 Full-time health departments, the PHS maintained, were necessary "to carry on to a logical conclusion the preventive measures started [following the flood]."172 Given lack of local funds, however, the likelihood of the affected states and counties creating new health departments without outside help was slight. ${ }^{173}$ The obvious solution was an expansion of the PHS's existing rural sanitation program.

In June 1927, representatives of the PHS and the Rockefeller IHB, meeting in New Orleans, agreed to attempt to expand their county health programs to reach all of the counties devastated by the flood. County governments quickly proved amenable to their efforts. By the end of October 1927, sixty-seven new counties had entered into cooperative agreements with either the PHS or the Rockefeller IHB. Within a year of the flood, seventy-eight counties, "or about 92 per cent of the total with which contact was made [by agents of the Public Health Service and International Health Board]" had signed on the program. ${ }^{174}$

Where county money was too scarce for even a small appropriation, the PHS and the IHB, along with state boards of health, wholly "financed the projects temporarily with a limited personnel. In many counties, the work was made possible by donations from the local Red Cross chapters, municipalities,

170. Lumsden, "Cooperative Rural Health Work of the Public Health Service in the Fiscal Year 1927," 2594-95.

171. J.H. O'Neill, "Relief Measures During and Following the Mississippi Valley Flood," American Journal of Public Health 18, no. 2 (1928): 159.

172. Townsend, "The Full-Time County Health Program Developed in the Mississippi Valley Following the Flood," 1202. "In view of the preventable-disease disaster with which every populated county in the United States not provided with efficient health service is frequently visited," wrote Leslie Lumsden, "there appears sufficient reason why there should be an increased rate of development of efficient whole-time county health service in every section of the United States." Lumsden, "Cooperative Rural Health Work of the Public Health Service in the Fiscal Year $1927, " 2595$.

173. Townsend, "The Full-Time County Health Program Developed in the Mississippi Valley Following the Flood," 1202.

174. Ibid., 1202-3. See also The Rockefeller Foundation, Annual Report for 1927 (New York: The Rockefeller Foundation, 1927), 145; O'Neill, "Relief Measures During and Following the Mississippi Valley Flood," 159. chambers of commerce, and civic organizations."175 In the short term, the PHS paid for the expansion of its county health efforts in the lower Mississippi Valley with money released from its "epidemic fund," designated for use in emergency situations. ${ }^{176}$ Congress, meanwhile, proved responsive to requests from the PHS for increased funding.

Impressed with the PHS's response to the flood disaster and willing, given the emergency circumstances, to endorse its continued involvement, Congress more than quadrupled the annual appropriation for "special studies of and demonstration work in rural sanitation" in the following fiscal year. Beginning in the summer of 1928, Lumsden had a $\$ 347,000$ appropriation at his disposal, up from an initial appropriation of $\$ 85,000$ in the preceding fiscal year. Of the new appropriation, $\$ 85,000$ was slated for "general use" and the remaining \$262,000 was earmarked for use in designated counties within the Mississippi flood zone. ${ }^{177}$

PHS officials could barely contain their excitement. "While deploring the frightful disaster of last spring," J.G. Townsend wrote in the PHS report on the county health program's post-flood expansion, "some comfort may be obtained in the knowledge that better communities are built on the ruins of those destroyed, and, as a rule, a better public-health regime may be inaugurated. Surely in this experience there has developed another flood-a flood of sanitation development which has placed us many years ahead of our old program of full-time county health service." 178

175. Townsend, "The Full-Time County Health Program Developed in the Mississippi Valley Following the Flood," 1203.

176. First Deficiency Appropriation Bill, 1928: Hearing before the Subcommittee of House Committee on Appropriations in Charge of Deficiency Appropriations, Seventieth Congress, First Session (Washington, DC: GPO, 1927), 631; Flood Control: Hearings before the Committee on Flood Control, House of Representatives, Seventieth Congress, First Session, on the Control of the Destructive Flood Waters of the United States (Washington, DC: GPO, 1928), 3074; Mead, Public Health Bulletin No. 222: History of County Health Organizations in the United States, $1908-33,5$. The amount of $\$ 180,740$ was released from the "epidemic fund" for the development of county health departments in the flood zone. The use of this money was authorized by Secretary of the Treasury Andrew Mellon and by President Coolidge.

177. L.L. Lumsden, "Cooperative Rural Health Work of the Public Health Service in the Fiscal Year 1928," Public Health Reports 43, no. 48 (1928): 3154.

178. Townsend, "The Full-Time County Health Program Developed in the Mississippi Valley Following the Flood," 1207. Testifying before the House Committee on Flood Control, Surgeon General Hugh Cumming suggested that "largely due to the action taken there has been actually in many respects an improved health condition." In response to Cumming's enthusiasm, Chairman Frank Reid felt it necessary to caution Cumming that he had not intended to prompt the Surgeon General "to give the impression that the flood was good for the health of the people there." See Flood Control: Hearings before the Committee on Flood Control, House of Representatives, Seventieth Congress, First Session, on the Control of the Destructive Flood Waters of the United States, 3074-75. 
Rather than endorsing a massive and permanent expansion of the county health program, however, members of Congress had intended to respond to an emergency situation. Convenience was a far greater factor in congressional approval than the arguments of PHS officers, which continued to center on the interstate threat of disease and its economic impact.

When Assistant Surgeon General Warren F. Draper, the veteran of rural sanitation work who at that time was heading the PHS Division of Domestic Quarantine, appeared before a House Appropriations Subcommittee, Representative William R. Wood (R-IN) highlighted the gap between PHS actions and reigning conceptions of the appropriate role of the federal government: "Have [the states in the flood zone] shown that they were unable to take care of the situation without Federal aid?" Told that they had, Wood wondered whether the states had given the PHS "an account of the money that they have available for state expenses, etc.?"

"Here is the trouble," Representative Wood told Dr. Draper: "When these disasters come, of course we help them in every instance, but they ought to understand that they ought not to abuse the generosity of the Government by using the Federal Government to do for them what they ought to do for themselves when the disaster is over." 179

To Representative Wood, whatever health benefits the PHS effort was bringing to the region appeared to be outweighed by its significant risks, particularly the likelihood that the federal government was "establishing some very dangerous precedents by doing this sort of thing." 180 Although Assistant Surgeon General Draper detailed the economic benefits of public health work and sought to reassure the committee that PHS involvement would not be indefinite, Representative Wood was unwilling to endorse the expansive vision of the PHS's role that the county health effort represented. "You want to encourage these people," he concluded, "to help themselves and make them understand that the Government is not going to keep doing this for them forever. If we are, we are going to exhaust the Treasury before long." 181

\section{THE DROUGHT}

As it turned out, Congressman Wood's concern about the precedent being set was well placed. Previously an

179. Second Deficiency Appropriation Bill, 1928: Hearing before the Subcommittee of House Committee on Appropriations in Charge of Deficiency Appropriations, Seventh Congress, First Session (Washington, DC: GPO, 1928), 466.

180. Ibid., 469 .

181. Ibid. ignored and small-scale initiative, the PHS's rural sanitation program achieved a degree of national legitimacy following the Mississippi flood. State and county governments throughout the lower Mississippi Valley, meanwhile, now had extensive experience in cooperating with PHS officers.

During the spring of 1930, a massive drought, concentrated in Arkansas, overcame much of the South. The Department of Agriculture described it as the "worst drought ever recorded in this country." ${ }^{182}$ Particularly in the lower Mississippi Valley, the drought had severe effects for farm families counting on a decent harvest to pay back the debts they had incurred both to survive and to plant the year's cotton crop.

Following a substantial delay, during which President Herbert Hoover favored minimal federal intervention in the drought area and reliance on the emergency efforts of the Red Cross, Congress began passing relief measures for the drought area. Aware that the drought was exacerbating already poor health conditions, senators from the drought area pushed for the expansion of the PHS's rural sanitation program as part of the federal response to the crisis.

Arguing for the enlargement of the PHS program, Senate Minority Leader Joseph Robinson (D-AR), Senator Alben Barkley (D-KY), and other proponents could now rely on evidence of its success in limiting disease, a broad base of local popular and political support, and, crucially, the example of 1927. As Arthur T. McCormack, Kentucky's state health officer, explained to the Senate Agriculture Committee, the precedent for federal intervention in public health in the drought area was unambiguous: "This proposal is based upon the action taken during the Mississippi flood under the leadership of President Coolidge and Secretary of Commerce Hoover."183

182. Milton E. Eisenhower, ed. United States Department of Agriculture, Yearbook of Agriculture 1931 (Washington, DC: GPO, 1931), 1.

183. Emergency Appropriation for Cooperation with State Health Departments in Rural Sanitation, Etc., Hearing before the Committee on Agriculture and Forestry, United States Senate, Seventy-First Congress, Third Session, on S. 5440, a Bill to Authorize an Emergency Appropriation for Special Study of, and Demonstration Work in, Rural Sanitation (Washington, DC: GPO, 1931), "Statement of Dr. A.T. McCormack," 2. The apparent contrast between Hoover's role during 1927 as Secretary of Commerce and his administration's restrained approach to the 1930-1931 drought crisis was often referenced by the proponents of a more vigorous federal response. "If the President of the United States could be fully informed as to conditions," Joseph Robinson said in a statement taking issue with the chairman of the Red Cross's assertion that the agency could handle the situation in the drought area, "if the Secretary of Agriculture would do what President Hoover did as Secretary of Commerce in 1927-go in person to the regions, visit the homes of the people, confer with those familiar with conditions-we wouldn't be disputing in the Senate and conflicts would not arise between the two houses of Congress as to what means are desirable for relief." See "Robinson Pleads for Drought Area,” New York Times, January 8, 1931. 
Whatever opposition to federal intervention in local affairs might have been expected from southern leaders was absent. Asked whether there was any local "opposition to Federal work of this kind," McCormack replied that " $[\mathrm{t}]$ here is the general opposition to Federal aid of any kind. But there is no specific opposition, and so great was the improvement in the situation following this other work [in the aftermath of the 1927 flood] that in no county in the flood area during this period has there been any opposition to this work by anybody." 184

As McCormack, Surgeon General Hugh Cumming, Assistant Surgeon General W.F. Draper, and Arkansas state health officer C.W. Garrison testified before the Senate Agriculture Committee, their descriptions of the PHS's actions in the South were met with knowing recognition. At one point, Senator Thaddeus Caraway (D-AR) interrupted Assistant Surgeon General Draper to extol the virtues of federal public health work. Praising the efforts of the PHS following the 1927 flood, Senator Caraway declared that he was "so thoroughly persuaded that there is no work the Government does which pays such a dividend as this in the matter of public health, that I feel there could be no objection to it, because a strong healthy population is most important . . . It contributes more to the national welfare than otherwise could be contributed. I live in the valley of the Mississippi, and we know of what tremendous importance this is." 185

A large collection of letters solicited by C.W. Garrison, Arkansas state health officer and head of the Conference of State Health Authorities of North America, further demonstrated the growing breadth of support for and interest in the PHS's cooperative program. In letter after letter, state and county officials testified to the urgency of the public health situation and need for federal support. James M. Smith, a county judge from Desha County, Arkansas, explained that his home county needed money to continue to pay for a health officer, nurse, sanitary inspector, vaccines and antitoxins for typhoid and diphtheria, and brewer's yeast, which was quickly becoming an established public health expenditure for the prevention of pellagra throughout the South. The people of Desha County, Judge Smith wrote, "have begun to appreciate" the importance of the county's public health programs. "We feel sure that the death rate has been lowered considerably during the past three years." What advances had been made, Smith believed, were likely to be lost if the county's public health board was allowed to be discontinued.

184. Emergency Appropriation for Cooperation with State Health Departments in Rural Sanitation, Etc., Hearing before the Committee on Agriculture and Forestry, United States Senate, 6.

185. Ibid., 16.
Evoking the reasoning long-employed by federal public workers, Judge Smith drew attention to the economic significance of disease. "I feel reasonably sure," he wrote, "that a continuation of the health program in this county would be worth $\$ 3$ for every dollar it might cost. Well and healthful people are not only able to earn more money and produce a great deal more crops, but there is a great saving in doctor bills, medicine bills, and funeral expenses." "I cannot help but feel," he continued, "that our own Senator Robinson, with the able assistance of our other Senator and Congressmen, will be able to convince the Congress that the physical welfare of our people is a matter of grave and paramount importance." 186

The expanded rural sanitation appropriation was included in a drought relief package passed as part of the Senate version of a larger Interior Department appropriations bill. Both President Hoover and the Republican House leadership, however, opposed the relief package. As the debate over the proposal became increasingly acrimonious, Senate Democrats threatened to block any version of the appropriations bill that failed to include it. ${ }^{187}$

Confronted with this threat, and the support of a number of western Republican Senators for the relief package, the Hoover administration and House Republicans backed down. On February 6, 1931, Hoover signed the appropriations bill, including the drought relief package, into law. ${ }^{188}$ It contained an additional $\$ 2$ million for the operation of the PHS's rural sanitation program in the droughtstricken areas. The existing appropriation for the 1931 fiscal year had been for only $\$ 338,000 .^{189}$ Acknowledging the weak economic condition of participating counties and states, the new authorization did not require local matching funds for "cooperative" projects. ${ }^{190}$

When it came time to reauthorize the PHS effort in the drought area a year later, the enthusiasm of many members of Congress for the program was palpable. Senators Alben Barkley (D-KY) and Josiah Bailey (D-NC) testified to the need for the

186. Ibid., "Letter from James M. Smith to Dr. C.W. Garrison, dated December 28, 1930," 165. In addition to being submitted and reprinted along with the other letters from local public health officials, Smith's letter was read aloud by C.W. Garrison during his testimony.

187. "House May Delay Relief Bill Action," New York Times, January 23, 1931; "Senate Democrats End Congress Truce as House Kills \$25,000,000 for Relief," New York Times, January 31, 1931; "Senate Foes Compromise on $\$ 24,000,000$ Drought Aid," New York Times, February 6, 1931.

188. As signed, the appropriations bill was the outcome of a conference committee. There were no roll-call votes on the public health provisions of the bill.

189. Mead, Public Health Bulletin No. 222: History of County Health Organizations in the United States, 1908-33, 5.

190. Annual Report of the Surgeon General of the Public Health Service for the Fiscal Year 1931 (Washington, DC: GPO, 1932), 87-88. 
continuation and expansion of the cooperative program, while Charles McNary (R-OR), chair of the Senate Agriculture Committee, wondered aloud whether the program should be extended into the Northwest. ${ }^{191}$

At the 1931 peak of its drought intervention, the PHS's rural sanitation program supported work in 375 full-time county health departments. As of 1933, the PHS was operating in 126 counties, up from 69 in 1927. In the interim, the PHS had assumed a role as the dominant outside force in the development of local public health work in the United States. The total number of counties that it operated in now exceeded those of the Rockefeller IHB, and where the two agencies both funded health departments, money from the PHS was dominant (Figure 6). ${ }^{192}$

\section{POLITICAL SUPPORT}

Speaking before the American Public Health Association in 1919, nearly a year after the end of World War I, the PHS's Leslie Lumsden had suggested that "[o]f all peoples, we of the United States should profit from the lessons of the war. We have discovered our strength. We used that strength gloriously to help win the war." He continued, "We have discovered also some of our weaknesses." ${ }^{\prime 193}$ Pointing to the achievements of the United States in limiting disease in the Panama Canal Zone and in the wartime extracantonment zones, Lumsden maintained that these successes would be of little long-term importance if public health workers could not develop political support for the expansion of their efforts. Governments, Lumsden told the members of the American Public Health Association, responded to "the apparent popular demand for each of the activities. This seems natural and proper under government by the people. Until our people generally become awakened to not only the absolute value but also the relative value of public health work our legislative bodies can not be expected to grant the authority and funds necessary for public health advancement on a reasonably adequate scale." Public health workers, Lumsden argued, needed to "convey to the people the facts from which properly may be drawn a popular public health perspective." 194

191. Demonstration Work in Rural Sanitation: Hearings before the Committee on Agriculture and Forestry, United States Senate, Seventy-Second Congress, First Session, on S. 1234, a Bill to Authorize an Emergency Appropriation for Special Study of and Demonstration Work in Rural Sanitation (Washington, DC: GPO, 1932), 808.

192. Mead, Public Health Bulletin No. 222: History of County Health Organizations in the United States, 1908-33.

193. L.L. Lumsden, "Public Health Perspective," American Journal of Public Health 9, no. 12 (1919): 931.

194. Ibid., 933.
In the years following World War I and even more so in the aftermath of the 1927 flood and 1930-31 drought, officers from the PHS had generated a great deal of political support for federal intervention in public health at both the state and local level. Writing to the Surgeon General in 1929, Division of Domestic Quarantine head Warren Draper described the situation in Louisiana. Though Governor Huey Long had ousted Oscar Dowling, the long-time head of the State Board of Health, Long supported the state's cooperative work with the PHS. Where Dowling had operated "a highly centralized organization," the "rural sanitation work, on the contrary, is administered mainly through local officials and is as much decentralized as work under general State and Government supervision can be." As a result, the work was "quite enthusiastically supported by the Governor and all of the others who were opposed to the centralized plan." ${ }^{95}$

During the 1928 state legislative session (a successful one from the perspective of rural health work), the PHS's C.V. Akin wrote to Draper that "[e]very Parish Police Jury [the Louisiana equivalent of a board of county commissioners] from Parishes with Health Units is sending in a strong resolution which is read before the House and Senate. I am told that these resolutions are developing a tremendous influence for the [state rural sanitation] appropriation." ${ }^{\prime 96}$ Eight of the thirteen members of the state's House Appropriations Committee, Akin noted in another letter, came from counties that had been flooded in 1927. In addition, the state police jury association had endorsed the PHS's work and recommended "liberal appropriations by the State." 197 In 1930, the Louisiana State Legislature passed a resolution memorializing "the Congress and the President of the United States of America ... to effect passage of legislation placing the financial assistance and the cooperation of the United States Public Health Service [with states] on a permanent and more liberal basis." 198

195. "Memorandum for the Surgeon General—Regarding the public health situation in Louisiana, with especial reference to the detail of Doctor Akin," May 23, 1929. Records of the Public Health Service, General Subject File, 1924-1935. State Boards of Health. Louisiana- Cities and Counties (A-T) 0665-2323. Box 409, NC-34, E-10, NWCH, HM 1999.

196. C.V. Akin to Warren Draper, May 28, 1928. Records of the Public Health Service, General Subject File, 1924-1935. State Boards of Health. Louisiana-Cities and Counties (A-T) 06652323. Box 409, NC-34, E-10, NWCH, HM 1999.

197. C.V. Akin to Warren Draper, May 22, 1928. Records of the Public Health Service, General Subject File, 1924-1935. State Boards of Health. Louisiana-Cities and Counties (A-T) 06652323. Box 409, NC-34, E-10, NWCH, HM 1999.

198. Louisiana House Concurrent Resolution No. 14, By Dr. Drouth, Adopted by the House of Representatives and concurred in by the Senate June $12^{\text {th }}, 1930$. Records of the Public Health Service, General Subject File, 1924-1935. State Boards of Health. 


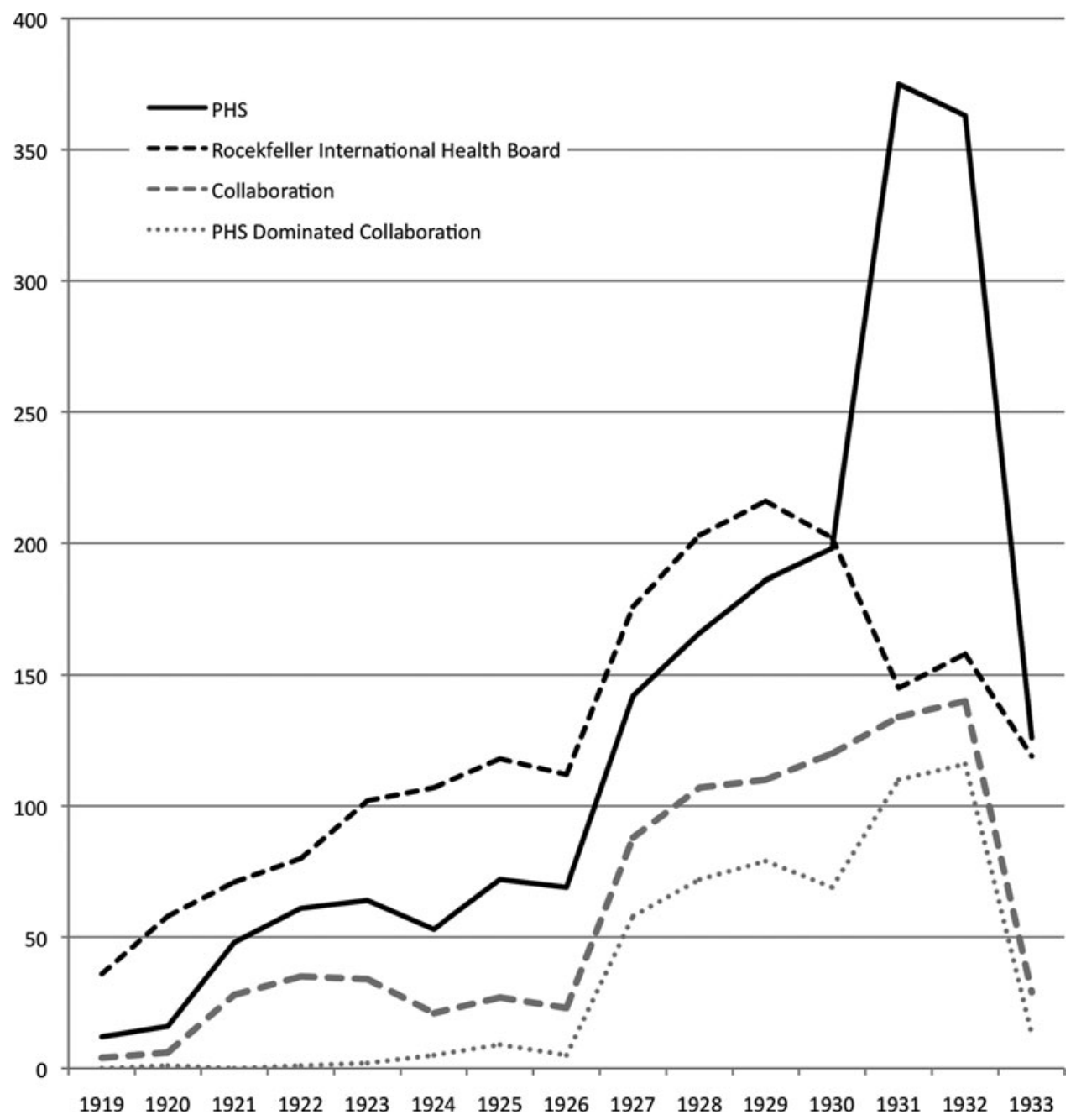

Fig. 6. Full-Time County Health Boards receiving support from the Public Health Service and Rockefeller International Health Board, Full-Time County Health Boards which the organizations collaborated in funding, and PHS/IHB collaboration counties in which contributions from the PHS were greater than those from the IHB, 1919-1933. Source: Adapted from Ferrell and Mead, "History of County Health Organizations."

In neighboring Mississippi, state Health Officer Felix Underwood had, since assuming the position in 1924, effectively courted political support for his department and for the work of the PHS. In 1929, when he had believed (incorrectly) that the PHS intended to transfer C.P. Coogle away from LeFlore County and (correctly) that they planned to transfer another PHS man, T.H.D. Griffitts, Underwood had orchestrated a campaign of letter writing and phone calls to the Surgeon General from Mississippi's representatives in Congress.

Louisiana-Cities and Counties (A-T) 0665-2323. Box 409, NC-34, E-10, NWCH, HM 1999.
In a letter to the PHS's L.L. Williams intended to persuade him not to transfer Coogle and Griffitts, Underwood detailed the extent of the state's support for the PHS, listing the members of Mississippi's delegation to the U.S. House of Representatives, including Congressman John Rankin (D-MS), who Underwood noted was "a cousin of mine." Each one, Underwood wrote, had "consistently supported an adequate appropriation for and bills of interest to the U.S. Public Health Service." "I do not have to tell you about Senators Pat Harrison and Hubert Stephens," Underwood continued, "for the reason that you know that they have been the friends of the Public Health Service."

Of the PHS's Coogle, Underwood noted that "The planters are most enthusiastic and do everything he 


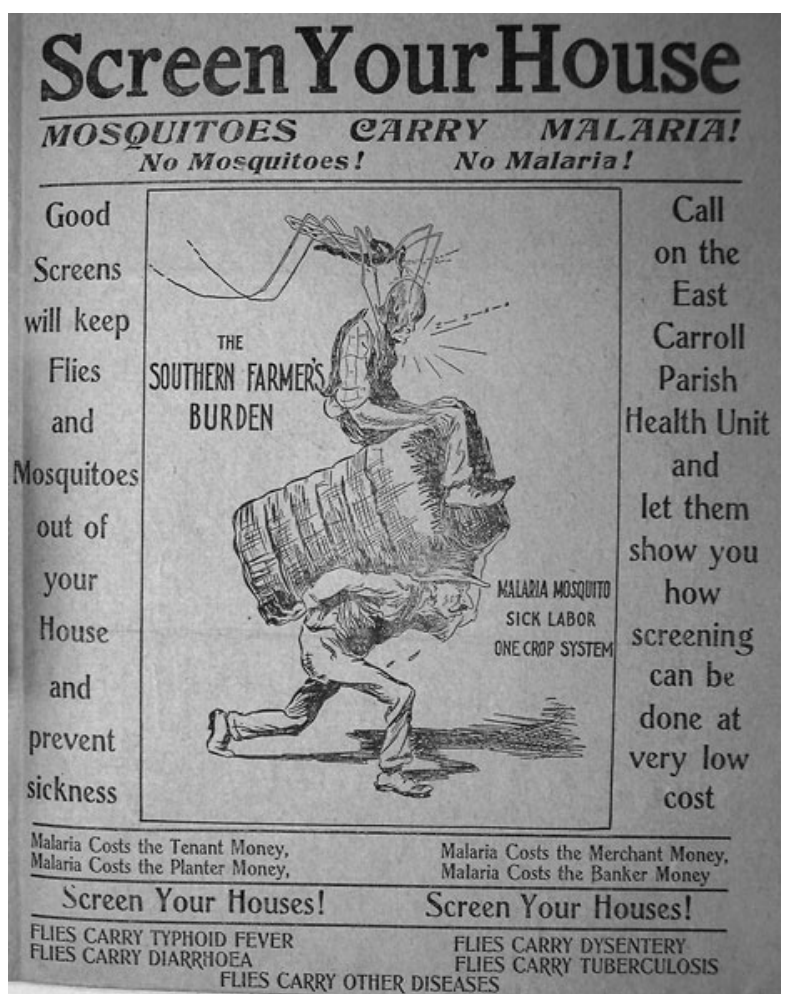

Fig. 7. "Publicity material," East Carroll Parish, Louisiana, circa 1929. Parish Health Department organized by George S. Bote, USPHS Office of Rural Sanitation. Source: National Archives, College Park, MD. RG 90, Records of the Public Health Service. General Subject File, 1924-1935. State Boards of Health. Louisiana- Cities \& Counties (A-T) 06652323, Box 409, NC-34, E-10, NWCH, HM 1999.

asks them to do without a word." Straining credulity, he wrote that "I am not writing this letter with the idea of attempting to pull any political strings, but to state the facts as I see them." ${ }^{199}$ As it turned out, Coogle was not being transferred, but instead had decided to leave behind government employment. Griffitts was transferred to Georgia, but with orders written so that he could continue to work at times in Mississippi. ${ }^{200}$ The extent of Mississippi's interest in the work of the PHS, nonetheless, was unmistakable.

199. Felix J. Underwood, Executive Officer, Mississippi State Board of Health, to Dr. L.L. Williams, PHS Office of Malaria Investigations, May 21, 1929. Records of the Public Health Service, General Subject File, 1924-1935. State Boards of Health, Mississippi, 0115-1340, Box 416, NC-34, E-10, NWCH, HM 1999.

200. L.L. Williams, Medical Officer in Charge, Office of Malaria Investigations, to Dr. Felix Underwood, May 27, 1929. Records of the Public Health Service, General Subject File, 1924-1935. State Boards of Health, Mississippi, 0115-1340, Box 416, NC-34, E-10, NWCH, HM 1999.

\section{SOCIAL SECURITY}

As of the early 1930s, war, the ongoing efforts of PHS officers, and two successive natural disasters had brought the federal government into an unprecedented role in the development of local public health infrastructure, concentrated largely in the southern United States. Generated over a long period of time, political support for the PHS ran deep. The longstanding efforts of PHS officers to court support for the rural sanitation program began to reap substantial legislative benefits in 1935, when the Social Security Act confirmed and further extended the federal government's emerging role. Title VI of the Social Security Act-transferred to the stand-alone Public Health Service Act in 1944endorsed for the first time the development and coordination of local public health work and infrastructure as a permanent goal of the national government. $^{201}$

Tasked with developing the proposals that would become the Social Security Act, the presidentially appointed Committee on Economic Security included a health advisory subcommittee whose members were well acquainted with both the unique health problems of the rural South and with the work of the PHS in the development of local public health infrastructure. Edgar Sydenstricker, the subcommittee's co-chair, had joined the PHS in 1915 and performed important early research on the causes of southern pellagra. He was now employed by the Milbank Foundation. Allen Freeman, a professor of public health at Johns Hopkins, had directed Virginia's Rockefeller-backed hookworm campaign during the 1910s and, as Ohio's state health officer, had been a vocal supporter of the failed Lever Rural Health Bill in 1919.

The subcommittee also included Mississippi's Felix Underwood, as firm a supporter of the PHS's efforts as could be imagined, a respected public health voice in both the South and the nation as a whole, and a man attuned to the connections between politics and public health. ${ }^{202}$ It was evident almost from the beginning that the subcommittee was irreconcilably split on the question of national health insurance. In part as a compromise, members of the subcommittee who opposed national health

201. See "Public Health Service Act, 1944," Public Health Reports 59, no. 28 (1944); William R. Willard, "Fifteen Years of Public Health Administration," Public Administration Review 10, no. 2 (1950).

202. For Underwood's comments on Title VI, see Economic Security Act: Hearings before the Committee on Finance, United States Senate, Seventy-Fourth Congress, First Session, on S. 1130, a Bill to Alleviate the Hazards of Old Age, Unemployment, Illness, and Dependency, to Establish a Social Insurance Board in the Department of Labor, to Raise Revenue, and for Other Purposes (Washington, DC: GPO, 1935), 415; Lucie Robertson Bridgforth, "The Politics of Public Health Reform: Felix J. Underwood and the Mississippi State Board of Health, 1924-58," The Public Historian 6, no. 3 (1984). 
insurance agreed to support the expansion of the PHS's rural sanitation program into a permanent and genuinely national endeavor, covering also public health work in cities. ${ }^{203}$ Accepting the recommendation of the subcommittee, the Committee on Economic Security's final report proposed a grant-in-aid system for the development of local public health infrastructure, to be administered by the PHS. ${ }^{204}$

Actively supported by prominent southerners, including Senate Finance Committee Chairman Pat Harrison (D-MS) and House Ways and Means Committee Chairman Robert Doughton (D-NC), the public health provisions of the Social Security Act were, in the words of Committee on Economic Security Executive Director Edwin Witte, "throughout the congressional consideration of this measure a source of strength for the bill." 205 Testifying before both the House Ways and Means Committee and the Senate Finance Committee, representatives of the PHS and the Treasury Department portrayed Title VI as an unobjectionable expansion of existing federal activities.

According to Surgeon General Hugh Cumming, who had been appointed to the position by President Wilson in 1920 and managed to retain it through the Republican administrations of the 1920 s, the provision for PHS-backed development of local public health infrastructure was "treading no new ground; it is an extension of an attempt on the part of the Federal Government many years ago which has been eminently successful. It is not a problematical thing."206

At the time, the PHS's single biggest appropriation was for the operation of Marine Hospitals, which consumed around $\$ 5$ million of the PHS's $\$ 10$ million budget. That the Service was largely focused on providing hospital care for sailors appeared to surprise some members of Congress. "In other words," Kentucky Congressman Fred Vinson exclaimed during

203. During his testimony before Congress, the PHS's C.E. Waller, who had succeeded Warren Draper as head of the Division of Domestic Quarantine, repeatedly appeared to suggest under questioning from Republican Allen Treadway of Massachusetts that the proposed public health grant-in-aid title would essentially change nothing about the PHS's existing work. Congressman Fred Vinson (D-KY) ultimately interrupted Waller to note that the work would indeed be different, since "this [funding] will be extended not only to the work in rural sections, but in small cities and large cities, too." See Economic Security Act: Hearings before the Committee on Ways and Means, House of Representatives, 319.

204. See Edwin E. Witte, The Development of the Social Security Act: A Memorandum on the History of the Committee on Economic Security and Drafting and Legislative History of the Social Security Act (Madison: University of Wisconsin Press, 1962), 172-73n. According to Witte, the opponents of national health insurance supported an expanded public health program as a means of diffusing calls for an insurance program.

205. Ibid., 171.

206. Economic Security Act: Hearings before the Committee on Finance, United States Senate, 408.
Assistant Secretary of the Treasury Josephine Roche's testimony during a House Ways and Means hearing, "half of the sum total that is generally said to be for public health went to the marine-hospital activity. Is there any connection between the marine hospitals and the public health services?" 207

Assistant Surgeon General C.E. Waller began his testimony by attempting to respond to Vinson's concerns about "what percentage of our total appropriation goes for health work. I may say that it is slightly over a million dollars [the rural sanitation program was at the time allotted $\$ 1,000,025$ annually], or a little over one-tenth of the total appropriation to the Public Health Service." ${ }^{208}$ Listening only briefly to Waller's remarks about the proposed new program, Vinson interrupted him in an attempt to further "paint the picture that I want to present to the committee." After describing PHS efforts to vaccinate school children in Kentucky, he professed to his fellow committee members that he was "perfectly willing to testify, because I have had personal observations and knowledge of how those things work, in my own country. It is the hardest-working crowd I know . . . they carry this preventive medicine into the roots of our rural society and, to my mind, it is the most splendid work that the Federal Government participates in." 209

In line with the geographical origins of federal involvement in the development of local public health capacity, Title VI was aimed to a great extent at addressing the health needs of the South. "The aids provided in this title," Committee on Economic Secuirty Executive Director Edwin Witte wrote, "were understood to be primarily for states in which public health work had been backward, due largely to state poverty. These were particularly the southern states, and the heads of the state departments of health in nearly all these states appeared before the congressional committees to endorse this part of the bill." 210

As enacted, Title VI authorized $\$ 8$ million in grants-in-aid for the development of state and local public health infrastructure and training of public health workers. Amendments to the Social Security Act in 1939 raised this figure to $\$ 11$ million. The formula for the allocation of Title VI funds took into account "special health problems," economic need, and the need for trained public health personnel. The enabling language, Witte noted, was "drafted

207. Economic Security Act: Hearings before the Committee on Ways and Means, House of Representatives, 312.

208. Ibid., 315. Later in the hearing, Vinson told Waller that he did "not see any logical connection between the marine hospital appropriation and the Public Health Service appropriation." See Economic Security Act: Hearings before the Committee on Ways and Means, House of Representatives, 321.

209. Economic Security Act: Hearings before the Committee on Ways and Means, House of Representatives, 316.

210. Witte, Development of the Social Security Act, 171. 
to suit the wishes of the United States Public Health Service."211 Reaping the benefits of a reputation developed through the efforts of PHS workers to develop local public health infrastructure and control diseases such as malaria beginning during World War I, the PHS received "broader discretionary power" through Title VI than "any federal agency in any other title." 212

\section{EMERGENCE OF THE CDC}

World War II and its immediate aftermath marked the culmination of the attempts to create a more fully integrated national public health system that had started during the previous world war. In September 1940, Congress passed legislation creating a peacetime draft; in March 1941, it approved the Lend-Lease program, granting President Roosevelt a great deal of leeway in supplying war matériel to support the British effort to withstand the Nazis. Meanwhile, the PHS's Division of States Relations, which administered Title VI funding, created a "Mosquito Control in Defense Areas" program in May of 1941.

In many respects, the situation resembled that of 1917. Importantly, however, there had been significant improvements in local infrastructure and capabilities. "As compared with the 1917-18 defense work," PHS Senior Sanitary Engineer E.C. Sullivan and Assistant Sanitary Engineer J.S. Wiley reported the month before Pearl Harbor, "better local health service facilities and experienced personnel are available at the present time than during the period of the previous World War."213

Headed by former Leslie Lumsden subordinate Joseph Mountin, the States Relations Division (formerly known as the Division of Domestic Quarantine) rapidly expanded its operations following the December 1941 attack on Pearl Harbor. In February of 1942, the division created a new "Malaria Control in War Areas" program, headquartered in Atlanta. By late March, malaria control operations were under way in the field. ${ }^{214}$

Broadly similar to the PHS's extra-cantonment zone effort during World War I, Malaria Control in War Areas could draw on a vastly larger budget, improved malaria control techniques, strong relationships with state and local leaders, and increasingly sophisticated public health infrastructure at the state

211. Ibid., 173 .

212. Ibid.

213. E.C. Sullivan and J.S. Wiley, "Sanitation Activities in the Southeastern States in Connection with National Defense," Public Health Reports 57, no. 17 (1942).

214. Annual Reports of the United States Public Health Service, 1941-42, 1942-43 (Washington, DC: U.S. GPO, 1943), 60. and county level. As a result of this preexisting infrastructure, a later PHS report concluded, "There was no loss of time in acquiring a background of knowledge of the malaria problem and of previous malaria control activities, such as malaria surveys and drainage and larviciding projects, and prompt advantage could be taken to permit institution or expansion of control measures where needed."215 Following the established pattern of the States Relations Division, Malaria Control in War Areas "carried on its malaria control activities largely within the framework of the State health departments." 216

The disease was far less of a problem than it had been only a decade before. In late 1933, the newly created Civil Works Administration (CWA) had initiated a large-scale and somewhat haphazard drainage program under the loose supervision of the PHS. Continued by the Federal Emergency Relief Administration after the CWA was discontinued in 1934, the drainage program was taken up by the federal Works Progress Administration in 1935.

Overseen by the PHS from the beginning, these drainage projects became increasingly effective after Title VI funds became available in $1936 .^{217}$ A later report by the U.S. Army found that, prior to mobilization for World War II, the public works agencies had dug 33,655 miles of ditches in the southern United States, "eliminating 544,414 acres of anopheline breeding area." ${ }^{218}$ From 3.7 deaths per 100,000 Americans in 1933, the malaria mortality rate fell to 2.1 per

215. Frank Tetzlaff, "Operation of the United States Public Health Service Malaria Control Program," Public Health Reports 63, no. 18 (1948): 557.

216. Ibid. See also Malaria Control in War Areas, 1942-43 (Atlanta, GA: U.S. Public Health Service, 1943), 34.

217. Margaret Humphreys has argued that the decline of malaria in the southern United States was a consequence of rural depopulation following implementation of the 1933 Agricultural Adjustment Act. See Humphreys, Malaria; Margaret Humphreys, "How Four Once Common Diseases Were Eliminated from the American South," Health Affairs 28, no. 6 (2009). An analysis of the decline of malaria in Alabama (relying on mathematical modeling of the disease and a novel data set including information on weather, rural and urban population, malaria mortality at the county level, number of tenant farms, and WPA drainage projects), however, shows that 1) high malaria mortality areas gained, rather than lost, population during the period of malaria's decline; 2) decreases in the number of farms operated by tenants did not result in depopulation and were not a cause of declining malaria mortality; 3) after weather, cumulative drainage was the variable most associated with declining malaria rates; 4) the release of Title VI funding during 1936 resulted in higher quality and more effective drainage work. This analysis may be found in George Mohler and Daniel Sledge, "Eliminating Malaria in the American South: An Analysis of the Decline of Malaria in 1930s Alabama," American Journal of Public Health (forthcoming).

218. Justin Andrews and Jean Grant, "Experience in the United States," in Preventive Medicine in World War Ii, Volume Vi, Communicable Diseases: Malaria (Washington, DC: Office of the Surgeon General, Department of the Army, 1963), 68. 


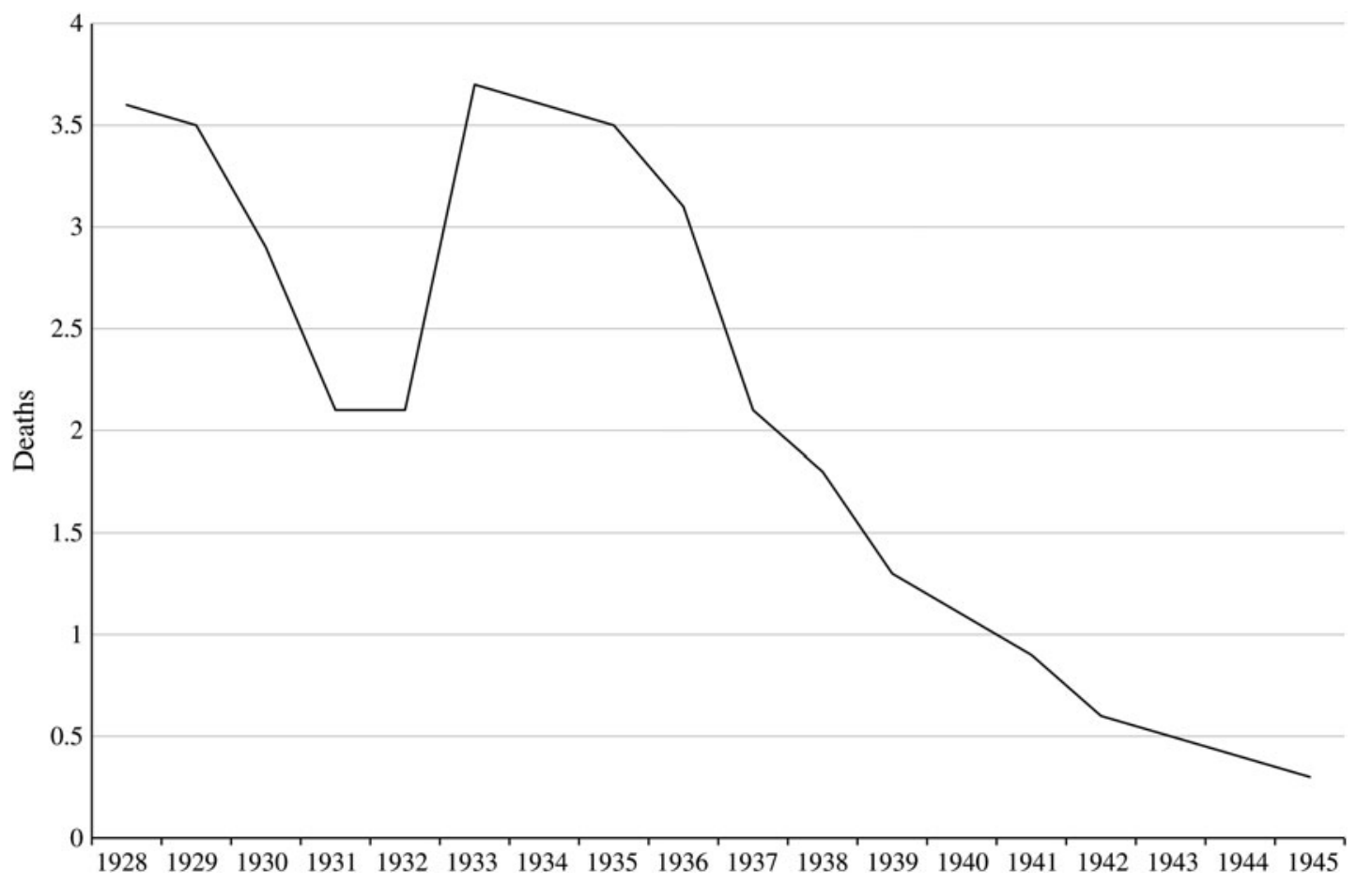

Fig. 8. U.S. Malaria Death Rate per 100,00 Estimated Population (Entire United States), 1928-1945. Source: Census Bureau, Annual Mortality Statistics, 1928-1936; Census Bureau and Public Health Service, Vital Statistics, 1937-1945. Note: Texas became the last state to enter the Death Registration area in 1933. The states included in the Registration area remained consistent from 1933-1945.

100,000 in 1937 . By 1940 , the rate had fallen to 1.1 (Figure 8). ${ }^{219}$

Nonetheless, the threat of malaria was real. ${ }^{220}$ Along with the danger posed by the remaining pockets of infection in the United States and internal population movements, prisoners of war from the malarial South Pacific and American soldiers who had fought there threatened to bring malaria into areas where it was not already present or provide additional sources of infection where it was. Beginning in November 1942, the Allied invasion of North Africa ensured that even larger numbers of Americans would come into contact with malaria that might be brought back to the United States.

By the end of 1944, the end of the war was imminent. "Military demobilization," the PHS's Louis L. Williams told the annual meeting of State and Territorial Health Officers in November 1944, "will

219. The methodology used to determine these rates and the number of states (forty-eight) within the Death Registration Area remained consistent throughout this period. Texas, the final state to join the Death Registration Area, was first included in 1933. See Mortality Statistics, 1933: Thirty-Fourth Annual Report, (Washington, DC: GPO, 1936), 37; Vital Statistics of the United States, Part I, (Washington, DC: GPO, 1939), 24.

220. See Grant, "Experience in the United States." introduce a large number of malaria carriers into the civil population. Some of the new strains will be more virulent than those we now have and will present a more difficult therapeutic problem. The greater relapse of Mediterranean and South Pacific strains will make these soldiers more dangerous carriers, as they will be more frequently infectious to the mosquito." ${ }^{221}$ However, no epidemic materialized. Despite large-scale population movements within the United States and the return of soldiers from the South Pacific, North Africa, and Italy, malaria mortality continued to decline throughout the war and into the postwar years.

The scope of the Malaria Control in War Areas (MCWA) Program grew substantially over the course of the war, expanding first into operations in southern cities against Aedes aegypti mosquitoes, the vector for both dengue and yellow fever. By the end of the war, MCWA had taken over the PHS's antimurine typhus activities in the Deep South and was inaugurating efforts against encephalitis and dysentery. Between July 1945 and July 1946, MCWA's Extended Malaria

221. L.L. Williams, "The Extended Malaria Control Program," Public Health Reports 60, no. 17 (1945):464. 
Control Program would spray approximately 400,000 homes with the new insecticide DDT. ${ }^{222}$

For Joseph Mountin, Surgeon General Thomas Parran, Jr. (another veteran of the "rural sanitation" program), and others in the PHS, the organization that the PHS had built in Atlanta during the war appeared to offer an excellent means through which to continue coordinating their efforts with state and local governments. Remaining a "field station" of the States Relations Division, MCWA was rechristened the Communicable Disease Center (CDC) on July $1,1946 .{ }^{223}$

Along with its ongoing antimalaria work, the CDC quickly emerged as a training center for public health workers from throughout the United States and even from abroad. ${ }^{224}$ Beyond the investigation and control of tropical diseases, the CDC acquired a reputation for its epidemiological prowess, centered in its Epidemic Intelligence Service, and its highquality laboratory work. Gradually, the CDC took over public health efforts that had been dispersed throughout the PHS. Emerging as the premier force in the coordination of health activities throughout the nation by the end of the 1950s, the CDC supplied both technical information and personnel to state and local health departments while embarking on increasingly sophisticated epidemiological studies. In 1960, the CDC began occupying new facilities in Atlanta on land donated to the PHS by Emory University. ${ }^{225}$ The same year, it gained control over the collection of national vital statistics, cementing its new role. ${ }^{226}$ Though the PHS continues to exist in the present day, its functions as far as disease control and the coordination of public health efforts have been almost entirely placed under the auspices of the CDC.

\section{CONCLUSION}

Throughout the first decades of the twentieth century, the successes of the United States abroad, and particularly in Cuba and the Panama Canal Zone, were a touchstone for those concerned with

222. Annual Report of the Federal Security Agency, Section Four: United States Public Health Service, 1946 (Washington, DC: GPO, 1946), 337.

223. Elizabeth W. Etheridge, Sentinel for Health: A History of the Centers for Disease Control (Berkley: University of California Press, 1992), 16-17; Thomas Parran, "A Career in Public Health," Public Health Reports 67, no. 10 (1952): 935. Etheridge provides a thorough account of MCWA.

224. See Etheridge, Sentinel for Health, 24; Ellis S. Tisdale, "A National Program for Training Public Health Personnel," Public Health Reports 66, no. 42 (1951); Trawick H. Stubbs, William S. Boyd, Paul P. Weinstein, "The Tropical Disease Education Program of the United States Public Health Service," Public Health Reports 61, no. 20 (1946).

225. "Highlights from the 1959 Report of the Communicable Disease Center," Public Health Reports 75, no. 12.

226. See Etheridge, Sentinel for Health, 115. the problem of tropical disease in the United States. Although the period of American international engagement that began with the Spanish-American War drew attention to health problems at home, it was not until the emergency of World War I that the federal government began to apply within the United States the techniques of controlling tropical disease that had been developed abroad. For those involved in the transformation of the role the federal government in American public health, the disconnect between American actions in places such as Cuba and the Panama Canal Zone and those at home was unmistakable. Equally clear, however, were the constitutional limitations on federal government authority at home.

Alabama congressman-later senator-Lister Hill's (D-AL) 1924 comments on the PHS's rural sanitation program are instructive: "To-day those who speak with authority tell us that malaria may be eradicated from any locality. The Federal Government, under Alabama's great son, William C. Gorgas, cleaned up Panama, and rid it of fever and disease. The Federal Government has done the same thing for Cuba and many parts of the Philippine Islands. Why should not the Federal Government render some aid to the State in the State's fight for the health of our people?" 227

In the years following World War I, PHS officers, at times cooperating with the Rockefeller IHB, attempted to retain some measure of the role that they had been thrust into by war. In the process, they developed a rationale for ongoing federal engagement in local public health problems that, buttressed by political support from states where the PHS had intervened following two successive natural disasters, underpinned inclusion and expansion of the PHS's county cooperative program in the 1935 Social Security Act.

When the United States became engaged in World War II, the PHS's efforts to aid states and localities in the development of local public health infrastructure and fight against tropical disease were further centralized in the Malaria Control in War Areas Program, renamed the Communicable Disease Center in 1946.

As a result of these efforts, debilitating diseases that were a central fact of southern life at the beginning of the twentieth century were for the most part eliminated by the end of World War II. Meanwhile, in attempting to confront the problem of tropical disease in the southern United States, federal public health workers developed institutions that dominate the practice of public health in the contemporary United States.

227. Congressional Record, Proceedings and Debates of the First Session of the Sixty-Eighth Congress of the United States of America, and index, Volume LXV-Part 3, House, February 9, 1924, 2200 . 
Federal power in public health continues to operate on terms that were pioneered during the 1920s: through grants-in-aid, the provision of

228. Grants-in-aid are, of course, one of the central means through which the federal government attempts to influence state and local policy. Notable examples include the use of federal funds to compel school and hospital desegregation, to lower speed limits during the 1970s-90s, and various attempts (such as "No Child Left Behind") to influence state and local educational policy. On the use of the Commerce Clause by the CDC to compel quarantine and isologation, see, for instance, Wendy Parmet, "Legal Power and Legal Rights-Isolation and Quarantine in the Case of Drug-Resistant Tuberculosis," New England Journal of Medicine 357 no. 5 (2007). The limitations on the federal government's ability to induce states to act through the use of grants-in-aid are not fully clear. As it stands, the Supreme Court has articulated the standard that grants-in-aid may not exceed the point at which the financial inducement offered by Congress turns from "pressure" into expert advice, and the constitutional authority of the federal government to regulate interstate and foreign commerce. ${ }^{228}$

"coercion." In 2012, this standard led the Supreme Court to declare some provisions of the 2010 Patient Protection and Affordable Care Act unconstitutional. As enacted, the law allowed the Secretary of Health and Human Services to discontinue Medicaid funding to states that failed to expand their Medicaid programs to include all individuals with incomes up to 133 percent of the poverty line. Writing for the majority, Chief Justice John Roberts argued that such a denial of Medicaid funds was impermissibly coercive. Since the states had agreed to participate in Medicaid under the assumption that its pool of beneficiaries would be limited to certain categories of individuals and could not now opt out of the program without foregoing substantial portions of their budgets, the new Medicaid requirements represented "a gun to the head." See National Federation of Independent Business v. Sebelius, 567 U.S. (2012), 51. 